\title{
REDES e CIDADES em REDES
}

TATIAHA GIOVAMONE TRAVISANI

ORIENTADOR-GILBERTO DOS SANTOS PRADO

\begin{abstract}
UNIVERSIDADE DE SAO PAULO ESCOLA DE COMUNICACAO E ARTES

PROGRAMA DE POS-GRADUACAO

ARTES VISUAIS-POETICAS VISUAIS MULTIMEIOS
\end{abstract}


UNIVERSIDADE DE SÃO PAULO

ESCOLA DE COMUNICAÇÃO E ARTES

\section{REDES e CIDADES em REDES}

Tatiana Giovannone Travisani

Tese apresentada ao Programa de Pós-Graduação em Artes Visuais, Área de Concentração Poéticas Visuais, Linha de Pesquisa Multimeios, da Escola de Comunicação e Artes da Universidade de São Paulo, como exigência parcial da obtenção do Título de Doutor em Artes Visuais, sob orientação do Prof. Dr. Gilberto dos Santos Prado.

São Paulo 


\section{Agradecimentos}

Ao professor e orientador Gilberto dos Santos Prado, pelo aprendizado adquirido na tese, no grupo de pesquisa Poéticas Digitais e nas aulas do programa PAE. A professora Silvia Laurentiz por estar sempre por perto desde o mestrado, ao professor Milton Terumitsu Sogabe pelo incentivo à pesquisa, ao professor e orientador Emilio Martinez pela recepção em Valencia e ensinamentos em arte público.

Aos amigos do grupo Poéticas Digitais de hoje e de ontem: Agnus Valente, Andrei Tomaz, Clarissa Ribeiro, Claudio Bueno, Daniel Ferreira, Luciana Ohira, Lucila Meirelles, Luis Gustavo Bueno, Mauricio Taveira (parceiro de todas as horas), Nardo Germano, Sérgio Bonilha, Renata La Rocca e Val Sampaio.

Aos funcionários da ECA/USP e da Facultad de Bellas Artes da UPV.

Aos professores do Master en Artes Visuales y Multimedios da Universidad Politecnica de Valencia, principalmente à profa. Maria José Martinez; à associação cultural Plutón e ao Laboluz. A Bia Santos, Ana Teresa Arciniegas e Isabel Gomez Mondragón pelas ajudas nos experimentos artísticos realizados.

À minha família pelo carinho e apoio de todo dia: Bruna Giovannone, a mãecompanheira-incentivadora; aos irmãos, cunhados, sobrinhos e tios.

À família Burgos e agregados, principalmente ao Fernando por todos esses anos dividindo as fortes emoções do universo acadêmico.

Aos amigos paulistas, mineiros, cariocas e valencianos, por estarem perto e compreenderem o estar longe.

Ao DeCo Nascimento pelas obras realizadas em parceria e inspirações criativas, pelo apoio atencioso e crescimentos compartilhados.

E finalmente à CAPES pelo incentivo financeiro da pesquisa no Brasil e durante o doutorado sanduíche em Valencia/Espanha.; e também ao CPG ECA-USP pelas bolsas PAE. 


\section{Resumo}

Este trabalho é uma reflexão sobre como as perspectivas de cidades vem sendo exploradas e representadas por experiências artísticas contemporâneas, tendo como universo o uso de dispositivos ligados em rede e abertas a participação e atualização contínua. Para isso utiliza referências históricas e teóricas, desenvolve análise de obras atuais e elabora experimentações artísticas autorais. A pesquisa é iniciada com a conceituação de rede e os caminhos percorridos pela arte, seguida pelas concepções da cidade contemporânea mediada e os movimentos artísticos provocadores de condutas transgressoras no espaço urbano. Nas análises das obras foram criadas tags para a identificação de elementos comuns às cidades atuais, utilizadas também como referência para elaboração dos experimentos criativos referentes a esse trabalho. Com isso, se propõe apontar alguns aspectos estéticos da relação criada entre as REDES e CIDADES em REDES.

Palavras-chave: arte em rede; arte e cidade; participação; redes; cidade mediada 


\begin{abstract}
This paper is a reflection about how city perspectives are being explored and represented by contemporary artistic experiences, having the universe as network connected devices, open to continuous participation and actualization. To achieve its goals, historic and theory references were used, actual arts analyses were developed and author artistic experimentation were created. The research starts with network concepts as well as the ways ridden by artwork, followed by mediated contemporary city conceptions and 'teasing' art movements from urban space transgressing 'behavior'. On artwork analyses, tags to identify common elements at actual cities were created, also used as reference to the elaboration to creative experiments related to this research. With this, it proposes some aesthetic aspects points of the relationship between NETWORK and CITIES in NETWORK.
\end{abstract}

Keywords: network art; art and city; participation; networks; mediated city 


\section{Sumário}

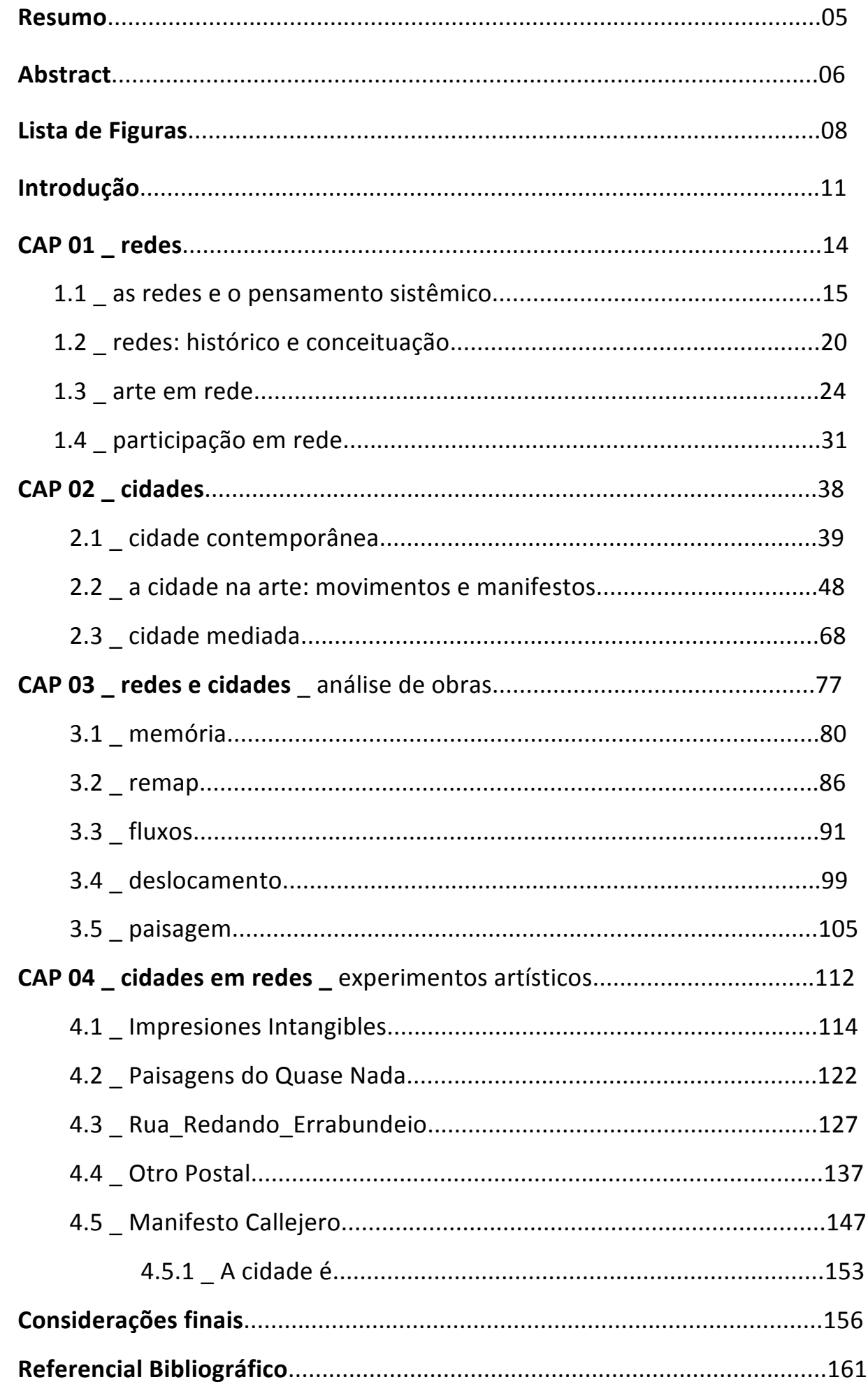




\section{Lista de figuras}

Fig 01 - Um dos resultados de City Portrait, concebido por Karen O'Rouke................26

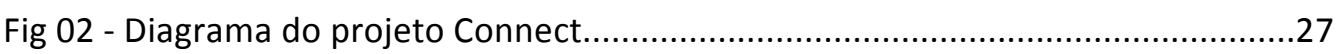

Figs 03 - Fragmentos de Good Morning Mr. Orwell, de Nam June Paik (1984)............28

Fig. 04 - Participação da artista Lali Krotoszynsky no Sky Art Conference, 1986

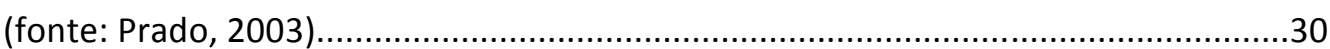

Fig. 05 - Fragmento da carta de Lygia Clark a Helio Oiticica (1968)............................32

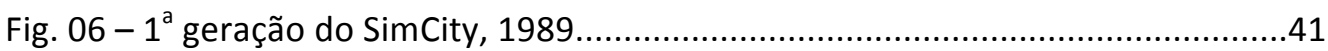

Fig. 07 - Versão mais atual do SimCity, previsto para 2013 .........................................41

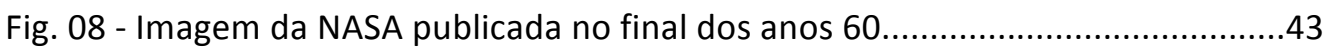

Fig. 09 - Dans La rue (1860), de Constantin Guys....................................................51

Fig. 10 - Fig 10 - La musique aux Tuileries (1862), de Édouard Manet.......................51

Fig. 11 - Vortice (1914), do artista futurista Giacomo Balla.......................................55

Fig. 12 - Grupo dadaísta à saída da expedição (1921)..............................................57

Fig. 13 - Capa do manifesto Surrealista de André Breton (1924)..............................60

Fig. 14 - Guia psicogeográfico de Paris (1957), Guy Debord.....................................65

Fig. 15 - The naked city (1957), mapa-obra criado por Guy Debord..........................65

Fig. 16 - Muro sendo criado por Ozi e Mundano, imagem disponível

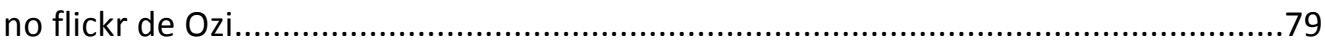

Figs. 17 - Algumas aplicações de Luce em Valencia (ES); imagens do flickr da obra...84

Fig. 18 - Intervenção de Luce em terreno, imagem da página do projeto.

Figs. 19 - Exemplo de um Dead Drops instalado sendo acessado por um usuário, imagens da página do projeto

Fig. 20 - Fig. 20 - Mapa atual (jan. 2013) da obra, print screem do site do trabalho..88

Figs. 21 - Mapas atuais (jan. 2013) da obra Sound Cities: geral e da cidade de

São Paulo, Print screem do site do trabalho

Fig. 22 - Desluz em exposição na Galeria Luciana Britto, São Paulo (2010), imagem de acervo do grupo

Figs. 23 - O cubo da obra e o resultado visual dos leds infravermelhos; imagens de acervo do grupo Poéticas Digitais.

Fig 24 - Amoreiras na Av. Paulista, em 2010; imagens de acervo do

Poéticas Digitais

Figs. 25 - Detalhes dos motores e das hastes de Amoreiras; imagens de acervo do Poéticas Digitais.

Fig. 26 - Uma das imagens feitas pelo autor da obra Capacities (2011)..... 
Fig 27 - Esboço criado pelo autor e disponível na página da obra, intitulado: "The Emergent City".

Figs. 28 - Imagens feitas por Cleyton, um dos usuários do Canal*MOTOBOY, disponíveis

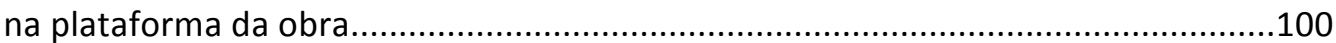

Fig 29 - Mapa atual (jan. 2013) do Canal*MOTOBOY, print screem da página...........101

Fig. 30 - Usuários-participantes do Canal*Motoboy, imagem disponível no site da obra

Fig. 31 - Mapa demonstrativo isomórfico da rede de trens, disponível do site 103

Figs. 32 - Mapas do fluxo de trens às 19:43 de uma quarta-feira, disponíveis no site.

Fig. 33 - Mapa recente (jan. 2013) de Communimage, print screen da página web..106

Figs. 34 - Exemplos de aproximação feitas no mapa de Communimage.....................106

Fig. 35 - Cartão postal gerado pela obra Communimage..........................................107

Fig. 36 - Communimage em exposição no MoMA de San Francisco (2009); imagem do portal Art and Electronic Media..............................................................................108

Fig 37 - O kit da obra A Guide to Getting Lost, imagem do site do artista....................109

Figs. 38 - O guia da obra A Guide to Getting Lost, imagens do site do artista.............110

Fig. 39 - Participante utilizando o mapa, imagem do site do artista.............................111

Fig. 40 - Homepage da obra Impresiones Intangibles (2012).....................................116

Fig. 41 - Mapa geolocalizado do bairro, com os logos do projeto como marcas (Google

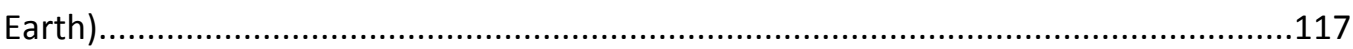

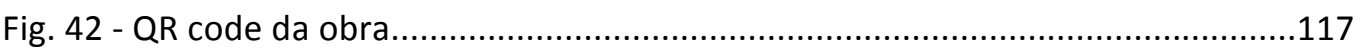

Fig. 43 - Exemplo de visualização das postagens......................................................118

Figs. 44 - Postagens da série Ilegadas....................................................................119

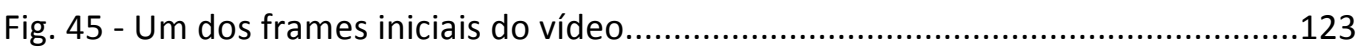

Fig. 46 - Frame de Paisagens do Quase Nada..............................................................124

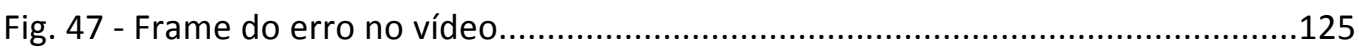

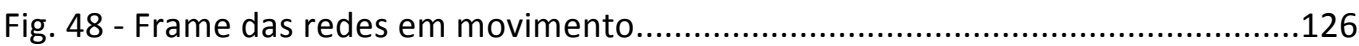

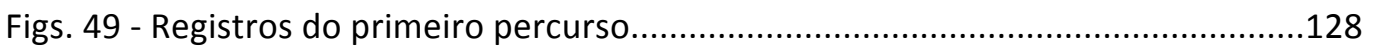

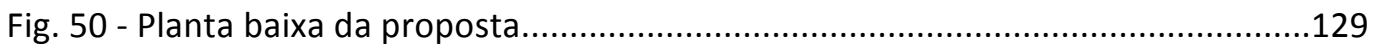

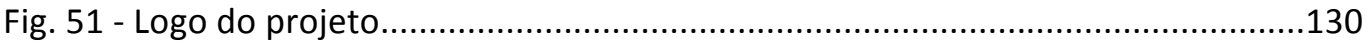

Fig. 52 - Patch do software Pure_Data construídos para a obra

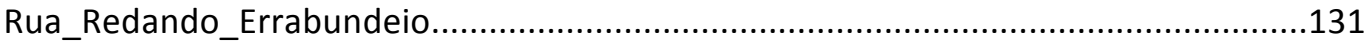

Fig. 53 - Símbolos do ka: o eterno errar (fonte: CARERI, 2009; 64)..............................132

Figs. 54 - Alguns fragmentos de imagens capturadas na rua de Valencia durante uma

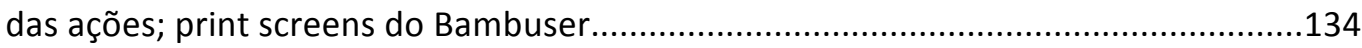

Figs. 55 - Alguns fragmentos dos resultados visuais da manipulação em Pure_Data de uma das ações da performance, em Valencia. 
Figs. 56 - Qr code da obra e sua aplicação durante a ação na cidade de Valencia. 136

Figs. 57 - Trechos da performance realizada na parte externa do Museu da República durante o \#11 ART, em Brasília (2012).....

Figs. 58 - Alguns modelos de cartões postais de Valencia, em sentido horário: catedral, fallera e paella, edifícios dos Calatrava e históricos e o mercado central (todos encontrados na internet).

Figs. 59 - Postais da obra: Balcón e Feria Alternativa. 139

Figs. 60 - Postais da obra: Mercat de Russafa e Fallera. .140

Figs. 61 - Postais da obra: Huertos Urbanos e Graffiti. .140

Figs. 62 - Postais da obra: Balcones e Protesto 140

Figs. 63 - Postais da obra: Hilo e Recuerdos .141

Figs. 64 - Postais da obra: Calimocho Del Jorge e Mi Ventana. .141

Fig. 65 - Uma das traseiras, essa do postal Feria Alternativa. .142

Fig. 66 - Mapa marcando as lojas onde foi realizada a acción kiosquêra.

Figs. 67 - Frames do vídeo da acción kiosquêra em algumas das lojas

Figs. 68 - Qr codes em alguns dos lugares: na maquete da catedral de Valencia, na Plaza Del Ayuntamiento, na Ciudades das Artes y de La Ciência (projeto dos irmãos Calatrava) e num posto do Valenbisi.

Figs. 69 - Envelope enviado a Emilio Martinez e Bia Santos (fotos de Bia Santos) .146

Figs. 70 - Alguns pontos etiquetados com o manifesto callejero na cidade de Valencia 148 à 151

Fig. 71 - Alguns dos adesivos do Manifesto Callejero 151 


\section{Introdução}

As cidades sempre foram fontes de inspiração poética independente do período histórico e da mídia de criação. Por meio de produções, podemos absorver a experiência de estar em lugares distintos, em espaços e tempos apontados pela sua representação criativa. Não é novidade que algumas cidades tenham ficado marcadas pelas obras de artistas que evidenciaram seus símbolos estéticos. Na arte pictórica podemos citar como exemplos a Paris de Monet, a Roma de Michelangelo, a Madrid de Goya e a Nova York de Andy Warhol.

No processo evolutivo das mídias e de seus usos com finalidades artísticas, as cidades continuaram a inspirar produções, caminhando junto a própria história da arte, como aponta Argan no livro: História da Arte como História da Cidade (2002). As cidades cresceram e configuram-se pelas grandes concentrações populacionais desde o século XIX. Pode-se dizer que estamos na era das megalópoles, essas imensas zonas urbanizadas e ocupadas pelo êxodo rural. A complexidade desses espaços de convivência, a arquitetura construída para abrangê-la e as conseqüências sociais e ambientais decorrentes desse processo, apontam características particulares do tempo atual.

A evolução das mídias também marca esse tempo, permitindo trocas de informações cada vez mais instantâneas e em menores dispositivos. O uso cotidiano de aparelhos celulares integrados em rede de conexão móveis via 3G, com GPS ligados a satélites que apontam sua localidade, e que também registram imagens e sons, enviados em tempo real por esse sistema integrado, é parte do comportamento humano da contemporaneidade. A vida nas cidades e com esses dispositivos representa novas maneiras de fruição.

Segundo Lev Manovich (2002; 163) em 1990 estávamos na descoberta do ambiente virtual, fascinados pela tecnologia digital e pela maneira como podíamos criar um espaço virtual. A partir de 2000, volta-se para questões físicas e realistas, onde a exploração do ciberespaço continua, mas com a proposta de representar ambientes e relações mais próximas à fisicalidade. Esse argumento é perceptível ao observamos algumas mudanças ocorridas nos últimos anos quanto às temáticas e 
formas de obras artísticas. Elas utilizam tecnologia e estabelecem interfaces com objetos, interatividade tátil e símbolos do cotidiano. Esses são alguns exemplos citados com certa freqüência. Voltar o foco à cidade, lugar de convivência social e de constante transformação física, também pode ser um sintoma colocado por Manovich.

Já não há como separar a experiência de estar no espaço físico e no espaço digital: olhar a cidade e retratá-la; divulgar e receber ao mesmo momento as atualizações do lugares percorridos; câmeras de vigilância geolocalizadas controlam e mapeiam o fluxo da cidade; dados e relações mediadas por nossas atuações na rede web. Esta presente co-existência possibilita direcionar a percepção a fortes níveis, criando distintas relações com a cidade.

A partir desse cenário, os artistas interessados em arte mídia, espaço público e ações políticas, estão propondo novas maneiras sensíveis de absorvermos esses distintos graus de experiências possíveis. Aliado ao que Manovich apontou a respeito da atração pela fisicalidade, podemos observar uma relevante quantidade de produções artísticas focadas na conjunção entre rede e cidades em redes.

Desta forma, a presente tese analisa criticamente trabalhos artísticos que possuem as cidades como inspiração poética e/ou hiper estrutura de atuação, e abertos a participação pública. Assim como, busca compreende o fenômeno recente do aumento de proposições artísticas relacionadas com esta temática.

Para isso, o estudo foi dividido em quatro partes. A primeira, um levantamento conceitual de redes, do pensamento sistêmico à participação colaborativa nas artes, focado na compreensão da sua origem e desdobramentos na ciência, até ser absorvido nas e explorado pelas artes.

A segunda parte é dedicada à reflexão sobre a configuração das cidades contemporâneas e de alguns termos surgidos com a finalidade de defini-las, tratando de suas grandes dimensões e complexidades. Também foi criado um percurso dos movimentos e manifestos históricos que propunham a exploração sensível nas cidades, do flâneur (século XIX) ao Manifesto Mobile (2005). A cidade mediada por dispositivos móveis, pela rede web, por tecnologias de geolocalização e 
o contexto social ao qual nos inserimos na atualidade, encerram a parte dedicada às cidades.

Com base nesse caminho teórico, na terceira parte nos atemos à análise de obras artísticas contemporâneas, criadas a partir do início do século XXI, que promovem maneiras distintas de percepção e fruição, oferecendo novas formas de vivenciar as cidades através de diferentes níveis de participação e de redes construídas com esses fins. Para essas análises foram criadas tags temáticas relacionadas ao que consideramos como possibilidade de identificar e reconhecer a cidade contemporânea, sendo elas: memória, remap, fluxos, deslocamento e paisagens.

Por fim, a quarta parte abrange a produção de experimentos artísticos autorais realizados durante o período da pesquisa, todos inspirados nos estudos teóricos e exploração de meios tecnológicos desenvolvidos durante esse percurso. A principal motivação dos processos criativos foi perceber as relações íntimas obtidas no cotidiano com o espaço urbano, identificar as camadas em redes que mediavam a experiência, e utilizar esse elementos como fontes criativas para a produção de trabalhos que estimulassem um estar poético nas cidades.

Com isso, a tese busca contribuir nas reflexões sobre a cidade contemporânea e como ela está sendo representada pela produção artística atual, sendo a rede o meio sensível de exploração poética; assim como nos procedimentos criativos autorais, que é parte desse mesmo universo de interesse. 
CAP.OI - REDES 


\title{
CAP 01 _ introdução às redes
}

\begin{abstract}
Nossas visões do mundo e de nós mesmos não conservam registros de suas origens (...) Daí que tenhamos tantos e renomados "pontos cegos" cognitivos, que não vejamos que não vemos, que não percebamos que ignoramos. Só quando alguma interação nos tira do óbvio por exemplo, aos sermos transportados a um meio cultural diferente - e nos permitimos refletir - é que nos damos conta da imensa quantidade de relações que tomamos como garantidas.
\end{abstract}

Maturama \& Varela (1983)

\section{1 as redes e o pensamento sistêmico}

Antes de entramos no campo das definições de rede e o histórico nas artes, é necessário compreender a rede enquanto pensamento. Pois o pensamento é contemporâneo ao conceito de rede e pode ser melhor elucidado ao analisarmos a teoria do pensamento sistêmico, que vem sendo estudada e posta em prática a partir da metade do século XX. Porém, foi concebida oficialmente em 1967 com o livro do biólogo austríaco Ludwing Von Bertalanffy Teoria Geral dos Sistemas, reconhecido mundialmente como um dos pioneiros estudos sobre sistemas.

Uma das principais características da Teoria dos Sistemas de Bertalanffy consiste na percepção da necessidade de se estudar não somente partes e processos isoladamente, mas sim considerar um organismo como a soma e relação entre essas partes, sustentando a visão "do organismo como totalidade ou sistema e visse o principal objetivo das ciências biológicas na descoberta do principio de organização em seus vários níveis" (Bertalanffy, 1973; 29). Chamou esse ponto de vista de "organísmico", onde a intenção era encontrar a organização e a ordem que unificava o organismo, "resultante da interação dinâmica das partes, tornando o comportamento das partes diferente quando estudado isoladamente, e quando tratado como um todo"( Bertalanffy, 1973; 53).

Outra característica fundamental da teoria é a divisão entre sistemas fechados e abertos: "dizemos que um sistema é 'fechado' se nenhum material entra nele ou sai. É chamado 'aberto' se há importação ou exportação de matéria" ( Bertalanffy, 1973; 167). Sendo um biólogo, o autor usou como exemplo as reações físico-químicas que 
podem acontecer com certo número de reagentes num recipiente fechado, sendo considerados sistemas fechados ao exterior, e contendo sempre componentes idênticos. Já um sistema aberto responde a alterações do meio, auto-regulando-se dinamicamente, numa contínua transformação de componentes materiais e de energia (Bertalanffy, 1973).

No livro Pensamento Sistêmico: o novo paradigma da ciência, Maria Vasconcellos nos mostra também o conceito de aberto e fechado de Wilden (1972), no qual refere-se a informações novas. O sistemas abertos seriam sensíveis e capazes de incorporar informação nova e, portanto, capazes de aprendizagem. "Nesses sistemas, as relações possíveis vão se estabelecendo à medida que vai acontecendo a interação com o ambiente" (Vasconcellos, 2002; 208).

A Teoria Geral dos Sistemas, de acordo com Bertalanffy, se propõe a ser uma ciência da totalidade, ou como uma disciplina lógico-matemática aplicável a todas as ciências que tratam de "todos organizados" (Vasconcellos, 2002; 196). Para o autor, o sistema é um todo integrado, cujas propriedades não podem ser reduzidas às partes, "o comportamento do todo é mais complexo que a soma dos comportamentos das partes" (Bertalanffy apud Vasconcellos, 2002; 200). Somente a soma não incorporaria a troca e as relações feitas dessa troca no sistema, o que acontece nesses estágios e como impacta o sistema e os sub-sistemas alimentados por ele.

A definição de sistema é um "conjunto de componentes em estado de interação" (Bertalanffy apud Vasconcellos, 2002; 198). Ou seja, a interação ou relação entre componentes é questão essencial ao sistema. Como afirma Vasconcellos (2002; 199): "é um aspecto central que identifica a existência do sistema como entidade, distinguindo-o de um simples aglomerado de partes independentes umas das outras (...) para compreender o comportamento das partes, torna-se indispensável levar em consideração as relações". E em outro momento coloca: "as relações são o que dá coesão ao sistema todo, conferindo-Ihe um caráter de totalidade ou globalidade, uma das características definidoras do sistema".

Um exemplo bem empregado de sistema foi colocado por Bateson, pesquisador de sistemas na mesma época de Bertalanffy. Ele concebeu a mente como um 
fenômeno sistêmico, característico dos seres vivos. A mente, segundo ele, não está na caixa craniana ou em outra parte do corpo, mas nas relações. "Os processos mentais não dependem, pois, da existência de um cérebro ou de características especiais dos sistema nervoso, manifestando-se não só em qualquer ser vivo, mas também em sistemas sociais e ecossistemas. Então a mente está na natureza, tornando coeso o tecido das coisas vivas" (Vasconcellos, 2002; 239).

Podemos então interpretar o sistema como uma rede, assim como a cidade. A rede precisa estar viva e depende de relações para ocorrer e a cidade é uma "mente" social e física adaptativa, um sistema aberto ao meio de mudança contínua. Mas são transformações baseadas em organização e auto-organização, outros conceitos discutidos na Teoria dos Sistemas.

Para Bertalanffy (apud Vasconcellos 2002; 204), não havia ainda nenhum estudo dedicado somente à organização, mas para a Teoria, organização é um sistema de variáveis mutuamente dependentes, ela "caracteriza-se pela existência de interações fortes e não triviais entre as partes que a compõe. Sendo elas de ordem biológica ou social possuem como referência o "crescimento, diferenciação, ordem hierárquica, etc (...) a organização não pode ser adequadamente medida, nem em termos de energia, nem em termos de informação". Ele propõe a concepção de mundo como organização: "pode-se assim pensar em seqüências, tais como: dos átomos às moléculas, das moléculas às células, das células aos organismos, destes aos grupos sociais".

Já a auto-organização teve base nos estudos dos ciberneticistas, quando colocavam que a lógica dos processos fisiológicos podiam ser representadas por redes neurais. Assim, "os cientistas perceberam, nessas redes, a emergência espontânea de padrões ordenados de funcionamento, a que deram o nome de autoorganização" (Vasconcellos, 2002; 241).

Bem após essas definições, o físico Fritjof Capra, no livro $A$ teia da vida, coloca que auto-organização é "a emergência espontânea de novas estruturas e de novas formas de comportamento em sistemas abertos, afastando do equilíbrio, caracterizado por laços de realimentação internos e descritos matematicamente por meio de equações não-lineares" (Capra, 1996; 80). 
É um conceito que faz reconhecer o ambiente urbano, se auto-organiza constantemente, de acordo com as ações freqüentes e intensas sobre ele. Principalmente em grandes centros, mas isso será mais detalhado posteriormente na pesquisa.

Outro conceito discutido no livro de Vasconcellos é a fronteira entre sistemas. Para a autora, o limite entre os sistemas não podem ser reconhecidos com exatidão pois as fronteiras em relação ao sistema e ao ambiente são dinâmicas e por isso não se pode traçar seu limiar. Citando Wilden (1972), nos coloca que a linha separadora entre sistema e ambiente é uma ficção que infelizmente pensamos ser concreta. Portanto define que "as fronteiras não são sistematicamente concebidas como barreiras, mas sim como 'lugar de relação' ou o 'lugar das trocas' entre sistema e ambiente"(Vasconcellos, 2002; 207).

Maturama \& Varela também discorrem sobre fronteira entre sistemas. Os autores não diferenciam sistemas abertos e fechados, não há oposição entre ambos. Utilizam a expressão autopoiesis determinando qualquer relação que haja para definir um sistema, o próprio sistema autopoiético é, no mesmo ato, produto e produtor, o único produto são eles mesmos. A interatividade, a troca, se dá com o entorno, então as fronteiras que resultam a própria organização autopoiética: "uma rede de transformações dinâmicas, que produz seus próprios componentes é condição de possibilidade de uma fronteira (...) uma fronteira, que é a condição de possibilidade para a operação da rede de transformações que a produziu como uma unidade" (Maturama \& Varela, 2001; 54). Para eles as fronteiras são as redes, as ligações constituintes que determinam um sistema.

Apesar de controverso, é provado que a origem da Teoria Geral dos Sistemas de Bertalanffy (publicada como livro em 1968) precede a Teoria Cibernética cunhada por Norbert Wiener em 1948. Bertalanffy diferencia as "ciências do sistema" como “organisistas"e "mecanistas". A organisista está associada à Teoria Geral dos Sistemas enquanto a mecanicista à Teoria Cibernética. Isto porque a Cibernética surgiu com a preocupação de estudar os chamados autômatos simuladores de vida ou máquinas cibernéticas, ou seja, como proposta de construir um sistema que reproduzisse, emulasse, os mecanismos de um sistema vivo. Já a Teoria Geral dos 
Sistemas surgiu com a preocupação de descrição da natureza inanimada, como coloca Bertalanffy: "de princípios universais aplicáveis aos sistemas em geral(...) quer seja de natureza física, biológica, quer de natureza sociológica, (desenvolvendo) 'princípios básicos' interdisciplinares" (Bertalanffy apud Vasconcellos, 2002; 187).

Para Vasconcellos, reunir as duas teorias é chegar ao que considera ser os desenvolvimentos contemporâneos novo-paradigmáticos das "teorias sistêmicas". Porém a autora reconhece que, baseada em Bertalanffy, a Teoria Geral dos Sistemas é muito mais ampla que a Teoria Cibernética pois ela abrange o funcionamento de sistemas com muitas outras características não exibidas pela máquina. Então que "o conceito de máquina não pode ser generalizado para todo tipo de sistema" , além de não ser uma teoria transdisciplinar (Vasconcellos, 2002; 227).

Vasconcellos propõe um novo paradigma da ciência baseado no pensamento sistêmico, colocando a teoria dos sistemas no centro de estudos transdisciplinares, um paradigma com uma nova visão e concepção do mundo, de conhecimento, implícita na atividade científica em suas teorias e práticas. É um pensamento aplicável, como ela mesmo conferiu, a áreas e temas distintos do conhecimento, e ao tratarmos de rede, cidade e arte, as adequações ficam bastante evidentes.

Segundo Capra, na ciência o foco nas redes começou na década de 20 quando ecologistas "viram os ecossistemas como comunidades de organismos ligadas em forma de rede através de relações e alimentação, e usaram o termo cadeias alimentares para descrever essas comunidades". A partir daí, pensadores de diferentes áreas relacionadas à vida começaram a usar modelos de redes em todos os níveis de sistemas, "vendo organismos como redes de células, e células como redes de moléculas, assim como ecossistemas são entendidos como redes de organismos individuais" (Capra, 2008; 18). Tendo a lógica dos organismos como referência e até metáfora, outras áreas foram se apropriando e criando novas conexões dentro de seu universo de pesquisa, ou mesmo ligando áreas distintas para promover o pensamento sistêmico.

Capra define rede como algo essencial à existência viva: "um dos principais insights do novo entendimento de que vida que está emergindo nas fronteiras avançadas das ciências é o reconhecimento de que a rede é um padrão comum para 
todo tipo de vida. Onde quer que haja vida, vemos redes" (Capra, 2008; 20). Sendo assim, o pensamento sistêmico baseado no que Capra nos coloca como rede, explica o organismo vivo e ativo das cidades contemporâneas as quais iremos refletir.

\section{2 _ redes: histórico e conceituação}

O conceito de rede foi percorrendo áreas distintas de conhecimento. Inicialmente desenvolvido nas ciências biológicas e fisiológicas, passou a ser incorporado nos estudos humanos, sociais, cognitivos, matemáticos, entre outros. É possível utilizar e interpretar conceitos de diversos autores, mas para a presente pesquisa foi escolhido um grupo específico para elucidar o tema proposto.

Fritjof Capra levou a teoria do sistema da física quântica também a seus estudos em redes sociais. Para ele, sistemas biológicos trocam moléculas em redes de reações químicas, sistemas sociais trocam informações e ideias em redes de comunicação (Capra, 2008; 26). Essa comparação e similaridade é colocada pelo autor para mostrar a ideia de insight do novo entendimento da vida nas ciências em geral, já citado anteriormente. O símbolo da rede é a percepção maior de que tudo está ligado, em escalas e níveis diferentes, em graus maiores ou menores, mas tendo vida, tendo relações, existe rede.

Ao autor, a lógica do padrão da rede celular de um organismo pode ser comparada ao sistema básico de organização em todos os sistemas vivos, inclusive para a realidade social, que nada mais é que um sistema vivo de vidas. O diferencial está no resultado gerado pelas redes, mas não na identificação de sua existência. A rede pode resultar em estruturas físicas, como de um tecido epitelial, ou em estruturas imateriais, como pensamentos. A diferença está que redes biológicas são redes de reações químicas, enquanto redes sociais são redes de comunicação que envolvem linguagem simbólica, restrições culturais, relações de poder, etc. (Capra, 2008; 22-23).

Mas o termo "rede" já era empregado por tecelões e cesteiros do século XVII referindo-se a trama têxteis. Depois começou a ser utilizado na medicina, primeiramente pelo médico italiano Marcello Malpighi (1628-1694) para descrever o 
"corpo reticular da pele". Pierre Musso coloca que pouco a pouco rede e corpo se confundem: a rede está dentro do corpo e reciprocamente, comparando-se ao seus modos de funcionamento (Musso, 2004; 19).

Já no fim do século XVIII a geologia buscou criar uma "ciência generalizada das formas e das redes" em estudos de cristais, para comparar a estrutura de cristais segundo a "lei dos decréscimos". Segundo Musso, a grande ruptura do conceito de rede ocorreu na entrada do século XIX quando a rede "sai do corpo", não sendo mais observada sobre ou dentro do corpo humano, percebendo-se que a rede pode ser construída, pode ser artificial. "O engenheiro a concebe e a constrói enquanto $o$ médico se contentava em observá-la. A rede pode ser construída, porque ela se torna objeto pensado em sua relação com o espaço" (Musso, 2004; 20). Algo que seria explorado de maneira intensa, anos após, pela cibernética.

Seguindo a lógica da rede construída, incorporada nesse período histórico, ela passa a ser objetivada como matriz técnica, utilizada como estrutura para a concepção de infraestrutura itinerária, de estradas de ferro e telegrafia, modificando, assim, a relação com o espaço e também com o tempo.

Musso resume os processos históricos de concepção de rede, da ideia ao conceito:

$\mathrm{Na}$ antiguidade, a ideia de rede já está presente como mito do vínculo, levado por uma visão biometafísica colocando em ressonância as circunstâncias internas do corpo físico com o da Cidade e do grande corpo do Cosmo. No século XVII, a rede apresentada como tecelagem e forma da natureza torna-se modelo de racionalidade observado ou construído e, no século XVIII, a rede identificada com o corpo determina uma visão biopolítica e econômica. Aí ocorre a mudança que faz da rede um conceito, uma representação do território e um artefato técnico para o enlaçamento do globo (MUSSO, 2004; 22).

O autor analisa vários conceitos de rede, incorpora questões de diferentes pesquisadores e áreas, até conceber uma própria, bastante pertinente e relevante pois considera três níveis diferentes de rede em sua definição. Mas antes constata que, de maneira geral, os autores concordam que fechar uma explicação para rede é difícil, pois trata-se de um termo concreto e abstrato ao mesmo tempo e dinâmico por essência. Anne Cauquelin ilustra bem esse pensamento colocando-o da seguinte 
maneira: "a imaginação da rede resulta de que a maioria das coisas do corpo humano estão escondida por dentro e dificilmente são acessíveis ao olhar e ao toque". Completa que a estrutura de rede é "como um vínculo invisível dos lugares visíveis" (Cauquelin apud Musso, 2004; 30-31).

Mas, seguindo os níveis do conceito estabelecido por Musso, o primeiro é que a rede é uma estrutura composta de elementos de interação, sendo eles os picos, os nós da rede, ligados entre si por caminhos ou ligações. O segundo nível refere-se a rede como uma estrutura de interconexão instável no tempo, e sua transição de uma rede simples a uma complexa (de uma rede a uma rede das redes) são consubstanciais à sua definição. O terceiro elemento da definição de rede de Musso é que a modificação de sua estrutura obedece a alguma regra de funcionamento. Supõe que a rede segue algum parâmetro estabelecido, respeitando alguma norma (eventualmente modelizável) que explica o funcionamento do sistema estruturado em rede (Musso, 2004; 31-32).

Essa definição pode ser aplicada tanto a sistemas biológicos e matemático, como a socioculturais. Mas ao mesmo tempo não nos deixa cair na ingenuidade de colocar que tudo é rede.

$\mathrm{Na}$ concepção de rede se encontram, freqüentemente, o "entre", que é essencial à sua compreensão. "Entre" seria o transporte, o que corre pela rede, o que faz a rede ser rede, pois sem "substância", sem relações, sem troca, não há rede. Fluxo é a expressão mais utilizada para explicar essa troca "entre" a rede ou entre redes.

Capra puxa a concepção de rede à ecologia, onde se tornou mais proeminente. Nessa linha, é o fluxo de energia e material ao qual permite o organismo vivo de gerar, reparar e perpetuar-se continuamente. Isso é o metabolismo vivo, é o fluxo orgânico. Naturalmente, o fluxo está presente em quase todas conceituações sobre rede, pois seria a "substância" de alimento ao sistema em rede, sendo no universo das ciências naturais ou sociais.

Ao explicar a sociedade em rede, Castells (2004) coloca a rede como um conjunto de nós interconectados. Para o autor, a sociedade em rede veio à tona com 
a junção de três fatores primordiais e conseqüentes. O primeiro se refere ao modelo de desenvolvimento industrial e a infraestrutura criada para tanto. O segundo fator foi devido aos projetos alternativos tomados, a partir da década de 60 , como meio de solucionar os problemas do início da crise do capitalismo, resultando em adotar valores comuns para as grandes nações mundiais. O terceiro foi a revolução das tecnologias de comunicação, iniciada na década de 70. Esses fatores condicionaram a formação de uma sociedade em rede ligada por esses nós conectados. Com níveis de intensidade diferentes, todos foram afetados por essa lógica. Os acontecimentos ocorridos a partir da era moderna, resultaram numa sociedade que refletiu todo o pensamento sistêmico já incorporado na ciência, ou seja, esse pensamento também foi desencadeado como rede afetando as ações e a forma da sociedade que se formava sobre essa nova perspectiva. Os dispositivos tecnológicos são a ponta final dessa sequência de fatores, representam todo pensamento encadeado durante o tempo.

Para Castells, as redes de comunicação são padrões de contato criados pelos fluxos de mensagem entre comunicadores através do tempo e espaço. Fluxos são trocas de informações entre o nó através dos canais de ligação entre nós, é o que está entre os nós.

Então o conceito de rede e de fluxo que será adotado durante a pesquisa referese, basicamente, aos três níveis definidos por Pierre Musso, somado ao que Castells considera a rede de fluxos nos meios de comunicação, podendo ser aplicados a demais sistemas tecnológicos ou sociais em rede. Conceitos seguidos pelo pensamento sistêmico advindo das ciências naturais e incorporados em tantas áreas de conhecimento, chegando até a configuração do comportamento social pósmoderno, de acordo com a teoria de Castells.

Como pode-se observar, a origem da sociedade em rede não está associada, como é de costume ver referenciado em discursos menos formais, ao advento da rede web. "A rede não é, por tanto, um fenômeno novo. Recente é o status teórico que adquire" (Moreira, 2007; 57). Mas é nítido que com o surgimento de tecnologia e dispositivos digitais integrados num único circuito, a rede se evidencia e adquire 
força e poder mais visível, aos quais todos os conectados fazem parte, em maior ou menor grau de atuação.

\section{3 arte em rede}

A arte em rede não surge junto aos dispositivos sem fio, ou mesmo com a rede internet. Antes dos equipamentos tecnológicos atingirem esse estágio permitindo a interconexão global, alguns artistas já incorporavam o pensamento em rede em suas obras. Não somente o pensamento como também a ideia de abertura da rede, da troca contínua de elementos ligados por e da interação.

Segundo Gilbertto Prado (2003; 40), a arte postal é o primeiro movimento da história da arte verdadeiramente transnacional, é a primeira manifestação artística a tratar a comunicação em rede em grande escala. Teve como marco inicial a fundação da New York Correspondence School of Art, pelo artista Ray Johnson em 1963, considerada como a "data de nascimento" da arte postal.

Mas antes disso era possível perceber suas primeiras manifestações em grupos como Fluxus, Gutai e o movimento do neodadá, que promoviam happenings e action paintings públicos e com participação coletiva. Eram as obras abertas que precediam as ações da arte em rede, iniciada pela arte postal.

A arte postal (ou mail art) foi um movimento pioneiro, também, no que se refere a uma produção independente do circuito tradicional da arte. Com características de produção artesanal, utilizando materiais alternativos com finalidade de circulação e de criação coletiva. Uma rede onde os atuantes eram tanto emissores, quanto receptores. Como coloca Nunes (2010), é possível identificar nessa ações, antecedentes das experimentações colaborativas da rede internet em trabalhos da web arte, que em seu inicio também era articulada numa produção paralela ao circuito artístico formal.

Eram elas cartões postais que circulavam nos mais diversos países, papéis via correio com desenhos colaborativos, notas de dinheiro com intervenções visuais, colagens fotográficas distribuídas via correio, até chegar a utilização de aparelhos 
mecânicos e eletrônicos que aceleravam a produção e a distribuição desses trabalhos.

Para Prado, a arte postal foi uma rede verdadeiramente internacional, com centenas de artistas participando intensamente em meios múltiplos. Desde o começo não era comercial, era sem censura e aberta a participação irrestrita. autor coloca a importância de relembrar o período histórico vigente (dos anos 60 aos 80), quando a maioria dos países atuantes no movimento passavam por regimes opressivos, de censura e tortura. Além disso as tecnologias eletroeletrônicas eram inacessíveis a praticamente todos indivíduos. Assim, a arte postal tornou-se a única forma de intervenção artística antiestablishment (Prado, 2008; 181).

No Brasil a atuação do artista Paulo Bruscky foi bastante importante, sua atuação de cunho político e provocadora divulgou a arte postal no país. Ele também foi o pioneiro em arte Xerox, entre outras experimentações artísticas. Outro destaque foi a curadoria da XVI Bienal de São Paulo (1981) de Walter Zanini, reservando um espaço exclusivo para a arte postal que tinha curadoria de Julio Plaza.

Fábio Nunes expressa bem o sentido da arte postal em seu papel de ruptura nas artes:

Além de questionar o próprio sistema social - a opressão e censura política da época - a arte postal também questiona o próprio sistema das artes (...) também o rompimento da relação fixa de papéis entre emissor e receptor, pelo caráter colaborativo das redes instauradas. Algumas vezes, os trabalhos não possuem uma autoria, convencional: sua passagem pelos nós da rede dilui a noção convencional de autoria, ao passo que as mensagens podem ser alteradas em qualquer momento. (NUNES, 2010; 43).

Logo após e até concomitantemente, iniciaram as primeiras explorações com máquinas de Xerox e fax, em busca de uma transmissão mais instantânea e dinâmica. A partir desse período pode-se desenvolver as bases de uma relação mais estreita entre arte e as telecomunicações, com artistas que criavam projetos de ordem global (Prado, 2008; 182). A arte em Xerox e fax foi caracterizada pela subversão, um exemplo foi a ação realizada por um grupo de artistas brasileiros, 
L'oeuvre du Louvre - invasões poéticas (1990), que consistia no envio de trabalhos artísticos via fax ao Museu do Louvre em Paris, localizados na cidade de Campinas (SP) "invadiram" o museu com a ação. O acontecimento foi espalhado para os principais canais de mídia do país da seguinte forma: obras de artistas brasileiros estarão no Louvre. Os artistas participantes da ação foram Anna Barros, Lucio Kume, Mario Ishikawa, Milton Sogabe, Paulo Laurentiz e Regina Silveira.

Mas um dos primeiros trabalhos realizados em fax, bem antes dessa invasão poética, foi o evento N.E. Thing CO, Trans Usi Connection Nscad-Netco em 1969, onde foi realizado uma troca de informações via telex, telefone e fax. Em 1970 um residente do Centre for Advance Visual Studies (MIT) enviou durante duas semanas imagens via fax para o Walker Art Center em Minneapolis.

Dois projetos bem interessantes ocorridos no final dos anos 80, início de 90 foram City Portraits e Connect. A proposta de City Portraits foi reunir artistas de nove cidades européias e americanas partindo de pares de imagens de entrada e saída (fotos e outros documentos) transmitidas aos parceiros, "os participantes eram convidados a perfazer caminhos e estabelecer retratos de cidades que não conheciam"(Prado, 2003; 25). O resultado da metamorfose entre as imagens eram intercambiadas via fax para que os próprios moradores das cidades passassem a ver as cidades pelo visão do outro: "uma viagem imaginária por si mesmo e pelo outro, com itinerários-retratos que se construíam durante o percurso"(Prado, 2003; 25).

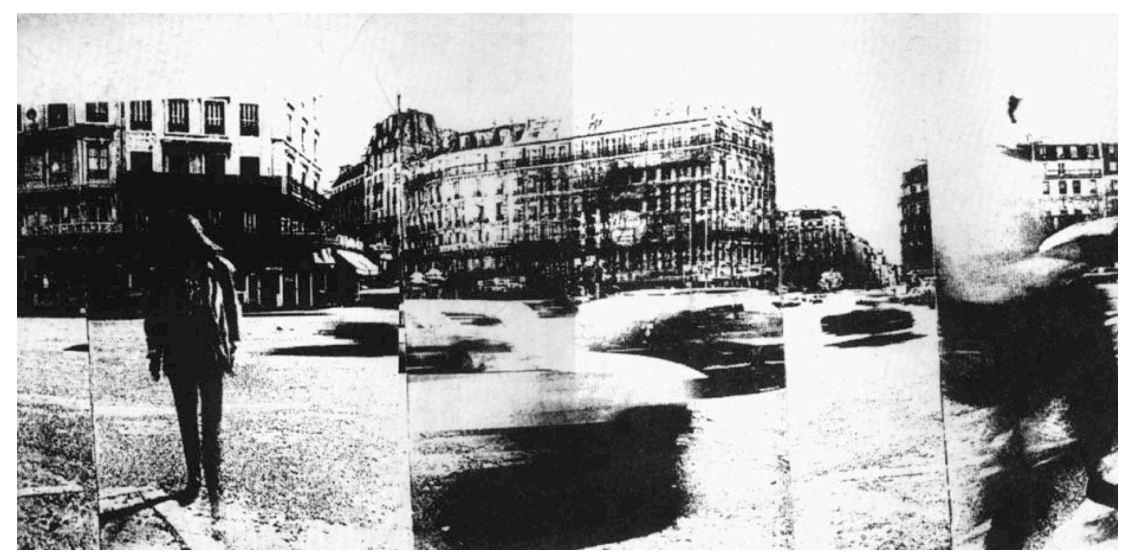

Fig 01 - Um dos resultados de City Portrait, concebido por Karen O'Rouke (fonte: Prado, 2003) 
Connect permitia, segundo seu autor Gilbertto Prado, a pessoas localizadas em diferentes locais do planeta realizar simultaneamente um trabalho artístico comum. Para isso, era preciso estar equipado com dois fax, um para emissão e outro para recepção (como mostra o diagrama abaixo). O papel que saia de um deveria ser encaixado diretamente no outro, assim se sucediam numa única longa página encadeada em tempo real, numa curva imaginária, interativa e efêmera desenhada através da rede artística de comunicação (Prado, 2003; 30).

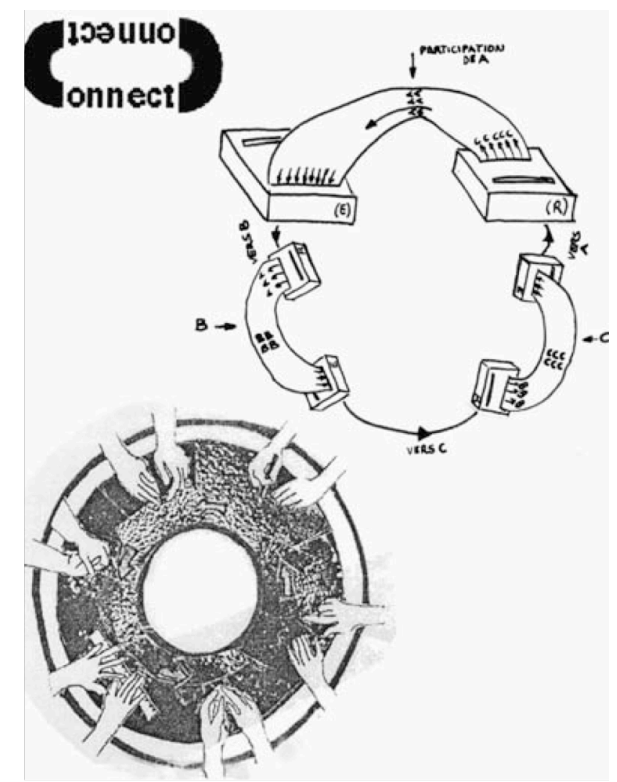

Fig 02 - Diagrama do projeto Connect (fonte: Prado, 2003)

Já com a Satellite Art foi possível utilizar meios de comunicação integrados via satélite nas propostas poéticas. Nam June Paik foi um dos precursores desses projetos. Com sua obstinação pela telecomunicação, ele buscava a metacomunicação para criar uma obra que fosse executada simultaneamente em locais distintos do mundo. Perseguiu por 15 anos essa exploração, bem sucedida ao final. Em 1977 inaugurou o Documenta 6 de Kassel com uma transmissão via satélite de performances realizadas ao vivo na Europa e nos Estados Unidos, chamada Nine Minutes Live. 
Também em 1977, Willought Sharp, Liza Bear e Keith Sonnier criaram em Nova Your o Send/Receive Satellite Network, uma rede de artistas ligados pelo nó em São Francisco, produzindo 15 horas de transmissão entre as cidades.

Em 1984 Paik desenvolveu outro projeto, o Good Morning Mr. Orwell, onde fez uma transmissão que, além de ao vivo, era participativa, incluindo na rede cerca de 50 artistas de várias nacionalidades. Reuniram-se em um mesmo espaço televisivo, simultaneamente, e atuaram ao vivo (Giannetti, 2002; 87). Segundo o próprio Paik (1976), o evento foi o primeiro uso global interativo de satélite entre artistas internacionais. Ele previa a importância desses experimentos artísticos não apenas para a arte, mas para toda a sociedade pós-industrial:

É preciso pensar em como alcançar uma coesão interativa entre as distintas partes do mundo, como solucionar os problemas de diferenças de horário, como jogar com a improvisação em relação ao determinismo, os ecos, os acoplamentos e os espaços vazios no sentido de Cage, e como superar, rapidamente, as diversidades culturais, as expectativas e a mentalidade das diferentes nações. A Satellite Art deve extrair o melhor destes fatores, criando uma sinfonia multitemporal e multiespacial. (PAIK apud GIANNETTI, 2002; 88)
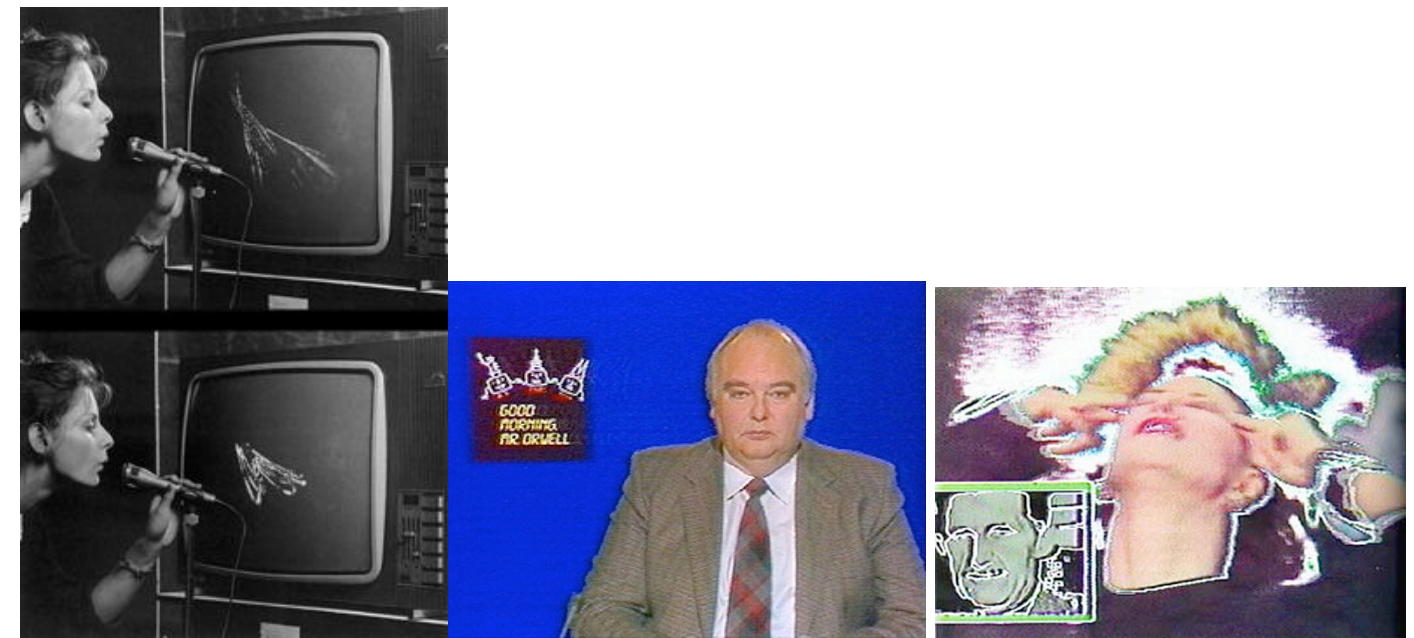

Figs 03 - Fragmentos de Good Morning Mr. Orwell, de Nam June Paik (1984)

No início da década de 70 também ocorreram as primeiras explorações da Computer Art. Temas como telecomunicação e arte associados à idéia de ubiqüidade foram naturalmente incorporados . 
Ainda mais ligado a satellit art, o espanhol Antoni Muntadas utilizou um canal de televisão regional, o Cadaqués Canal Local, para transmitir uma programação feita por ele e por sua equipe (colaboradores do povoado de Cadaqués). Essa experiência ocorreu em 1974, quando havia um único canal oficial de televisão na Espanha. A programação organizada por Muntadas, nessa espécie de televisão comunitária, era transmitida nos bares do povoado e nos cassinos, com o televisor funcionando como elemento socializante (Giannetti, 2002; 88). O que seria uma grade de programação comum tornou-se, dessa maneira, uma experiência artística, com a obra de arte onipresente em rede. Estava nas telas de locais variados da cidade, e estimulou reflexões não apenas sobre a produção de arte em telepresença, mas também sobre meio e mensagem.

É preciso ressaltar a produção de Fred Forest, também um dos primeiros artistas a "realizar trabalhos que utilizavam os meios de comunicação de massa de forma critica e exploratória, o telefone ou o vídeo para explorar as novas formas de criação que escapavam aos critérios tradicionais da arte"(Prado, 2008, 184). Suas obras entre os anos 60 e 70 foram muito relevantes para reflexões de arte em rede na época.

Em 1980 Roy Ascott desenvolveu o primeiro projeto artístico internacional de teleconferência feita por computador, através da rede Planet de Infomedia. O experimento conectou Ascott, na Inglaterra, a outros artistas, em Gales, Califórnia, Massachussets, Nova lorque e São Francisco. Foi uma transmissão via satélite e em rede, viabilizando plenamente o campo da arte da telecomunicação.

No Brasil, em 1983, Wagner Garcia e Mário Ramiro criaram Clones - Uma Rede de Rádio, Televisão e Videotexto. Consistia numa instalação com terminais de videotexto, monitores de TV, rádio e alto-falantes com a recepção sincronizada das três transmissões ocorridas no Museu da Imagem e do Som de São Paulo.

Em 1986 ocorreu no Brasil a primeira ação telemática interativa internacional no Sky Art Conference. Tratou-se de uma transmissão com slow scan entre artistas de São Paulo localizados no campus da USP e artistas americanos localizados no CAVS, em Cambridge. Em São Paulo foram transmitidas imagens vindas dos Estados Unidos vistas numa tela múltipla para 12 projeções de vídeo (Prado, 2003). 


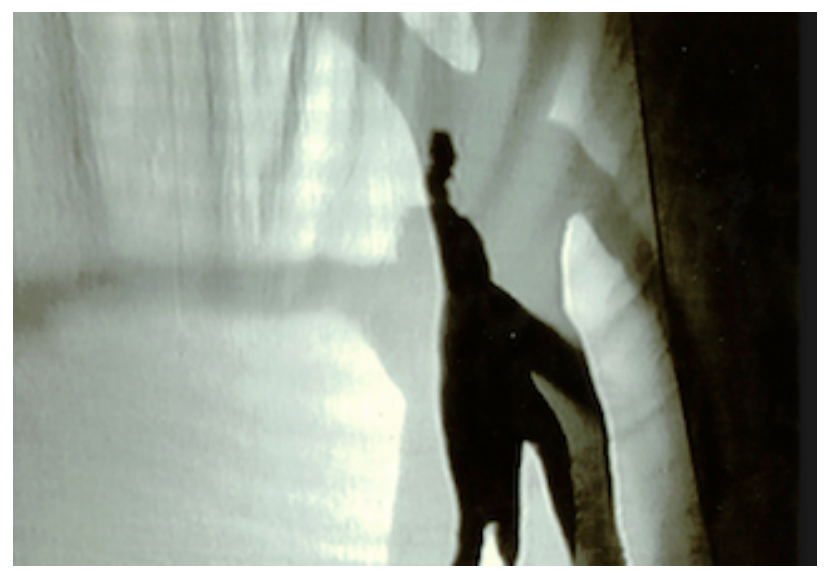

Fig 04 - Participação da artista Lali Krotoszynsky no Sky Art Conference, 1986 (fonte: Prado, 2003).

No início da década de 90 a rede de internet World Wide Web foi criada, permitindo a conexão direta entre computadores. Nessa rede, a ubiqüidade dos textos e imagens é a própria essência do sistema.

Na mesma década o grupo Ponton desenvolveu um experimento que uniu a técnica dos dois projetos citados anteriormente. Piazza Virtuale envolveu a telepresença e a participação pública num canal de TV. Foi realizado durante o Documenta de Kassel, de 1992. Utilizou o canal de televisão alemão ZDF, dois satélites e os estúdios eletrônicos do grupo Ponton, instalados provisoriamente numa praça de Kassel. Os estúdios estavam equipados com computadores conectados à rede e programados para receber chamadas telefônicas e informações via Internet. Durante 100 dias os telespectadores da cidade podiam conectar-se a esse canal e participar ativamente da programação através de seus telefones e modens. Observavam ao vivo a atualização do canal em sua própria televisão, dentro de suas casas (Giannetti, 2002; 92). Foi uma experiência inédita, explorando toda a potencialidade dos meios de telecomunicação. Ao final do projeto, contabilizou-se 130 mil chamadas recebidas, inovando uma grade de programação não linear, participativa e conjunta. Uma obra que dependia totalmente da participação do público para ocorrer. Além da técnica utilizada com os meios eletrônicos, permitindo a difusão de informação ao vivo, havia a percepção individual da participação ativa, como se houvesse uma representação própria de idéias ou pensamentos ocorrendo em locais distintos ao mesmo tempo. 
Assim, com a criação da internet www e dos dispositivos digitais, a computer art dá lugar a web art e todas as explorações sensórias e participativas vindas com essas possibilidades tecnológicas. A inclusão de novas máquinas, instrumentos e interfaces permitem novos procedimentos e experimentações. A arte em rede chega a um novo estágio exploratório onde a conexão global é essência, a proposta de abertura das obras é condição básica para suas existências e a interação acontece com variados graus de intensidade .

\section{4 _ participação em rede}

Ao discutir as noções de rede, Gilbertto Prado sugere a distinção em duas partes: uma relaciona-se à forma de trabalho, de ação/pensamento e de interação, e a outra na matriz técnica de transporte e de organização de informação (Prado, 2003; 33). É uma separação importante pois trata de reconhecer as funções e processos diferenciados da rede como estrutura processual, principalmente tratando-se do universo artístico.

Essas duas características de redes são orientadas por pessoas que participam da obra em rede, sendo seus elementos ativos. No primeiro caso como os indivíduos complementam a obra, são co-autores, interventores, interatores, atuam e são protagonistas temporários da proposta. No segundo caso também são peças chaves, transportam informações, impactando no sistema todo, "uma vez que o interventor se desloca a cada ponto da rede, carrega consigo todos os outros"(Prado, 2003; 33).

Nos trabalhos artísticos em rede o espectador constitui-se mais como um espect-ator (termo utilizado no teatro caracterizando o observador ativo, participante do espetáculo). Sua função é de catalisar ações que seguem e se encadeiam, interferindo no contexto de toda rede. A participação pública nas obras em rede é então essencial, é o alimento funcional dos trabalhos artísticos, nas duas partes características da rede já citadas.

Foi possível observar, mais evidentemente, as primeiras manifestações de participação pública nas propostas artísticas promovidas nos anos 60: as performances, os happenings, ready mades, algumas instalações. Até chegar a ser 
parte integrante da concepção da obra como no caso dos vestíveis de Hélio Oiticica e no conjunto da obra de Lygia Clark. Nesse momento o discurso era voltado mais à perda do objeto artístico único e central do que essencialmente em participação. A própria Lygia Clark dizia que o objeto, em seus trabalhos, havia perdido significância, e se usado, era para servir de mediador entre o participante. A ela, o mais importante era o corpo humano, a experiência ali promovida, a vivência poética do momento, tanto fazia se fosse através de uma luva ou uma pedra.

Oiticica, em cartas trocadas com Lygia (1968/1969), coloca a questão da participação como algo dificílimo de ser mensurada, havendo uma supervalorização e generalização naquele momento, por parte dos acadêmicos e críticos, a respeito da participação que as obras deles estavam promovendo. Mas que para eles o principal propósito não era esse, mas sim de criar novas oportunidades sensórias a cada indivíduo. Participação era um mero detalhe porque os artistas não poderiam medi-la, já que cada pessoa tinha experiências diferentes com seus trabalhos. O mais importante seria a forma de promover uma participação, com materiais e elementos simples, mas que provocassem vivências únicas às pessoas.

Lygia concordava dizendo não saber porque dava-se tanta ênfase na participação provocada pelas obras de ambos. Para ela, a questão relevante era o pensamento por trás da obra, o que a maioria das pessoas ignorava, o pensamento e a expressão, que em sua concepção estavam ligados.

\section{TRUE}

PARTICIPATION

IS OPEN

\section{WE WILL \\ NEVER BE \\ ABLE TO \\ KNOW WHAT \\ WE GIVE \\ TO THE \\ SPECTATOR AUTHOR}

Fig 05 - Fragmento da carta de Lygia Clark a Helio Oiticica (1968) 
Em 1962 Humberto Eco publicava sua célebre teoria sobre "obra aberta", a qual a participação era um dos temas abordados. Eco deu nome a uma série de trabalhos artísticos que estavam sendo apresentados naquele período. A partir daí, outros autores também passaram a discutir as novas criações que permitiam essa possibilidade de abertura ao público. Isso pode ter causado nos artistas brasileiros esse incômodo mal interpretativo de suas obras, vistos nas cartas trocadas por eles.

Alguns anos após, em 1968, Roland Barthes publica "A morte do autor", referindo-se à ideia de que o significado de um trabalho não depende da intenção autoral, mas do ponto de vista individual, de percepção dos que a usufruem. Barthes se preocupava primeiramente com literatura, mas seus pensamentos faziam analogias à maioria das produções artísticas contemporâneas da época.

Em 1969, Michael Foucaunt ministra uma conferência intitulada “O que é o autor?", possivelmente como resposta a teoria de Barthes. Isso demonstra o interesse nas questões de autor-público nesse momento. Conseqüentemente, a participação entrava nos discursos pois se encaixava no papel do público, já não sendo considerado passivo e espectador de obras, mas sim parte integrante devido tanto ao seu poder de interpretação, quanto a sua ação direta na fruição tátil e atuante, no caso das performances e ready-mades. Ambos pensamentos, de Barthes e Foucaunt, enfatizavam a crise da figura do autor, de seu papel diante de um cenário ainda experimental. Com a chegada da arte mídia e dos trabalhos propriamente interativos, essa discussão não se esgotou.

Porém, há um outro conceito surgido no início dos anos 90, levantado por Bourriaud, baseado na análise de obras de arte em função das relações humanas que a figuravam e suscitavam: a estética relacional. O preceito dessa teoria eram as relações humanas, o conjunto de relações não estabelecidas entre indivíduos, indo de encontro aos discursos que vinham de morte do autor, fim da arte, fim da historia. Discursos esses advindos num momento de mudanças bruscas nas configurações artísticas, em suas propostas, concepções e na absorção do que estava sendo criado. A estética relacional veio para explicar e dar luz ao que estava sendo mostrado e sendo observado com o critério da coexistência. Segundo Nunes: 
"o contexto toma uma importância que significa a perda da autonomia do objeto artístico, cada vez mais distante da ideia da 'arte pela arte'”' (Nunes, 2010; 74). Nesse caso, o contexto é o mais importante, e muitas manifestações surgidas desde os anos 60 eram intrinsecamente relacionais.

Ainda que trabalhe em um modo mais perceptivo, algumas obras de Lygia Clark também são exemplares no sentido de promover uma realidade relacional na qual se mantém uma conexão entre pessoas para uma exploração sensorial compartilhada, como em Nostalgia do Corpo (1965/88), em que a artista elabora objetos com finalidades relacionais para que cada indivíduo participante reconheça a si mesmo e ao outro (NUNES, 2010; 75).

Essas definições talvez fossem bem mais próximas daquelas incômodas em relação a participação, parece que Lygia Clark e Oiticica estavam em maior sintonia a esse tipo de pensamento colocado por Bourriaud. Mas o autor lançou o conceito no início doa anos 90 referindo-se à produção artística dessa fase. Colocava que essas obras iam no lado oposto das criações dos anos 80, mais interessadas em dar ênfase aos aspectos visuais proporcionados pelas mídias eletrônicas. Já os sucessores dessa geração, focaram na ênfase do contato humano, retomando a Arte Povera, a arte experimental dos 70, mas sem tornar o movimento num "revival". "The space in which their works are deployed is devoted entirely to interaction. It is a space for the openness (...) that inaugures all dialogues"( Bourriaud, 1998; 166).

O autor não se referia aos novos meios tecnológicos, para ele, naquele momento, os artistas que produziam imagens infográficas caiam na armadilha da ilustração, sendo sintomas de uma valorização de engenhocas, e da representação de uma alienação simbólica impostas por esses meios. Via que os principais efeitos da revolução informática eram visíveis em artistas que não utilizavam computador.

Porém, observamos que nas redes provocadas pelas mídias atuais, emergem-se novos contatos por elas mediados, constituindo novas formas de relacionamento. Já o que é feito e produzido com esses eventos cabe a outras discussões. Em espaços conectados por redes, as relações são essenciais, afinal, são elas que caracterizam as redes. Não é estética relacional, já que Bourriaud não incluiu as mídias no guardachuva de sua teoria, mas as relações feitas são extremamente importantes e necessárias. 
Segundo Laurentiz as relações já ocorrem individualmente, num processo não determinado simplesmente pelo fora e pelo seu entorno: "há uma tensão provida pelo individual 'em si' antes mesmo da tensão provocada por sua relação com os demais 'indivíduos' na qual passa a conviver". Ou seja, a relação já começa antes mesmo de ser compartilhada com outros seres, com outras coisas. E completa inserindo a rede: "(...) possuímos a capacidade de 'interfacear' com o mundo. Eu estou 'em/para' interações que faço com o mundo, além das que realizo em mim mesmo. A proposta é que ambientes de rede passam por um processo similar" (Laurentiz, 2004; 05). Esses ambientes ou esses espaços já existem por si, sem as relações externas, mas a capacidade de "interfacear" com o externo o abre a uma potência de relações.

Murray (2001) nos leva a pensar como serão, e estão sendo, construída as narrativas num ciberespaço. A autora sugere a inclusão do interator (como denomina o participante da obra) no próprio processo criativo, ele deve fazer parte de um enredo multiforme adotado para incorporar sua participação, já não tendo como estabelecer seqüências isoladas de eventos. Uma obra ou peça instaurada num meio como o ciberespaço já é por si participativa, já que depende, ao menos, da navegação de quem a usufrui. Para Murray, cabe ao propositor criar ainda mais abertura para permitir a colaboração nas performances.

Mas a autora dá ênfase na afirmativa de que o interator não é autor da narrativa digital, ele participa naquilo já pré-estabelecido pelo autor, dizendo não ser autoria, sim agência. "O interator é o autor de uma performance em particular dentro de um sistema de história eletrônica, ou o arquiteto de uma parte específica do mundo virtual, mas precisamos distinguir essa autoria derivativa da autoria original do próprio sistema" (Murray, 2001; 149-150). Seu poder de intervenção na obra tem um limite pré-estabelecido ao que ela chama de autoria procedimental.

Nunes (2010) nos coloca a importância no processo colaborativo, sendo muito menos do resultado individual de cada um, o mais relevante fica ao valor da inserção dos indivíduos nesse processo. Por isso a autoria processual, a figura do autor nos moldes clássicos não existe mais, não há objetos e obras fechadas em si, mas potencialidades. Sendo que a intervenção criativa dos participantes pode não se 
resumir ao que é imposto, mas se estender em potencialidades. "O autor procedimental não cria simplesmente um conjunto de cenas, mas um mundo de possibilidades narrativas"(Murray, 2001; 149).

O autor de sistemas abertos a colaboração promove, em muitas vezes, o participante mais do que a si próprio, ficando até "transparente"em sua própria obra. Mas ele é um propositor de possibilidades, não cabe aos participantes esse papel, podendo apenas chegar, em alguns casos, a extrapolar os limites imaginados pelo autor, a não ser que ele seja um ciberpunk intencionado a modificar o sistema.

Os trabalhos artísticos em rede não configuram as características de peças únicas, intocáveis, é o contrário disso. Como afirma Couchot: "a obra não é mais fruto somente da autoridade do artista, mas se produz no decorrer de um diálogo, quase instantâneo - 'em tempo real'- com o espectador'(Couchot, 1997; 140). Esse diálogo, presente e constante, é que diferencia as obras em rede das demais proposições artísticas. Em se tratando de trabalhos em rede utilizando sistemas tecnológicos, esse caráter fica mais evidente porque não é somente a rede como concepção poética ou pensamento, mas como ferramenta prática. Ascott define bem este fato:

O processo telemático, juntando por satélite, cabo, e fios de fibra ótica, uma vasta diversidade de entradas mundiais, celebra a morte do autor de imagens e textos "individuais" e "originais"; e traz à vida, em troco, um novo "autor disperso" - e interconectado, distribuído - gerando uma variedade massiva de autores, ao interior da "imaterialidade" virtual das redes. O desvanecimento da idéia de um autor só e original cede seu lugar à ideia da autoria múltipla (...) que se dá através das interações ou colaborações de múltiplos usuários dispersos pelos sistemas em rede. (ASCOTT, 2003;209)

Nessa perspectiva a rede promove entre autor e público um diálogo horizontal, não hierárquico, mais próximo a um "caminhar junto" do que "seguir atrás". É uma maneira de fazer olhar e sentir igual, não idolatrar. Vislumbrar o participante como conjunto da obra desde a sua elaboração inicial, não chegar a ele somente em sua apresentação pública. É essa possibilidade de diálogo que simboliza a participação na arte em rede. 
O autor convoca o participante, sua atuação exige uma certa responsabilidade já que impactará no sistema com um todo, e assim, na atuação de outros. É preciso o mínimo de doação para realizar o diálogo, estar entre, estar dentro das propostas. Como nos mostra Prado: " podemos considerar a rede um grande campo de ação nômade aonde os atores vão a 'descoberta' de coisas algumas vezes precisas, outras vezes encontram o acaso" (Prado, 2003; 36).

O participante nunca sabe até onde a obra pode levá-lo junto, até quanto pode interferi-la até experimentá-la. Sua interferência no sistema é essencial à obra, é o que o autor busca desde o início ao concebê-la. É uma poética de intercâmbio:

As redes permitem, ao menos aos que têm acesso a esses 'instrumentos de conhecimento/criação', sonhar juntos essa união e essa partilha (...) a cada troca/passagem, o artista/parceiro se engaja em um percurso de aprendizagem/participação que não se limita somente ao percurso em questão, mas que chama outros e ainda outros, em inumeráveis caminhos, lembrando o Jardim de Borges, cujos caminhos se bifurcam infinitamente. (PRADO, 2003; 36-37)

A participação em rede é uma participação colaborativa, possuindo níveis diferentes de atuação nas obras, dependendo da proposição artística. Sendo em alguns casos mais direta e visível, quanto o sistema reage instantaneamente a ação nela feita, podendo ser percebida no mesmo instante. Como também pode ser uma colaboração inconsciente do participante, quando, por exemplo, sua presença no ambiente é monitorada sem que ele saiba e esses dados são transmitidos à obra. Nesse caso a participação é involuntária, abrindo espaço a um outro tipo de discussão crítica sobre o papel do público na obra.

A arte, diferente da ciência, não se propõe a explicar de forma literal o funcionamento e as soluções técnicas dos eventos, mesmo daqueles que utilizam os dispositivos tecnológicos como meio criativo. Mas sim, a pensar maneiras e usos diferentes, e promover fenômenos sensórios poéticos com a exploração dos mesmos. O público partícipe, colaborador, é parte das discussões, integrante ou não de trabalhos em rede. Ao analisarmos obras artísticas mais à frente, vamos inserir pensamentos da participação no contexto e perceber os diferentes níveis da atuação que possam ser criados, e isso já demonstraria o quão diversas podem ser essas propostas. 
CAP.O2-CIDADES 


\section{CAP 02 _ Cidades}

\begin{abstract}
Se quiserem acreditar, ótimo. Agora contarei como é feita Otávia, cidade-teia-de-aranha. Existe um precipício no meio de duas montanhas escarpadas: a cidade fica no vazio, ligada aos dois cumes por fios e correntes e passarelas. Caminha-se em trilhos de madeira, atentando para não enfiar o pé nos intervalos, ou agarrar-se aos fios de cânhamo. Abaixo não há nada por centenas e centenas de metros: passam nuvens; mais baixo, entrevê-se o fundo do desfiladeiro (...). Suspensa sobre o abismo, a vida dos habitantes de Otávia é menos incerta que a de outras cidades. Sabem que a rede não resistirá mais que isso.
\end{abstract}

Calvino, 1990

\section{1 _ cidade contemporânea}

Encontramos muitos conceitos que nos ajudam a buscar uma possível maneira de discutir e definir a cidade contemporânea. Devido a tanta complexidade e transformações permanentes, é um tema em recorrente discussão entre os urbanistas, sociólogos, filósofos e programadores. Escolhemos alguns desses conceitos que nos ajudam a refletir sobre questões e mais do que fechar, buscamos relacioná-los junto aos autores a seguir.

Até a era moderna, menos de três por cento da população mundial morava em comunidades de mais de cinco mil pessoas. A grande maioria habitava regiões rurais e exerciam funções voltadas à subsistência e ao comércio. Hoje em dia, mais da metade vive em ambientes urbanos, com maior incidência nas grandes regiões metropolitanas do planeta, como a da cidade de São Paulo, por exemplo, que possui quase 20 milhões de habitantes.

Uma das marcantes características das cidades contemporâneas é a super dimensão demográfica e territorial atingidas em permanente movimentação e crescimento. É um fenômeno reconhecido mundialmente gerando muitos espaços de análises e propostas freqüentes de "sustentabilidade" para convívio pacífico ante aos conglomerados. Steven Johnson chama as grandes cidades de superorganismos e nos coloca: " o sucesso do superorganismo urbano pode ser o evento global mais 
significativo dos últimos séculos" (Johnson, 2001; 72-73). O autor refere-se as relações sociais e a emergência, considerando um dos elementos-chave da vida urbana. Para o autor, é preciso pensar as cidades na escala de superorganismos, comparando-as aos estudos com colônias de formigas e os sistemas de aprendizado e organização. "Em termos quantitativos, nossa espécie agora é composta de habitantes de cidades"(Johnson, 2001; 73).

Em sua teoria, há uma auto-organização nas cidades que vai além das organização impostas pelas leis. São comportamentos coletivos, na democracia popular para formação de comunidades que geram de maneira espontânea um padrão que inclusive ajudam na criação de novas leis, causados pelo fluxo e pela troca de conhecimento e informação adquiridas pelo convívio, pelo entorno habitado e pelos recursos usados pelo grupo. "O corpo aprende sem consciência, $e$ também as cidades, porque aprender não quer dizer apenas estar consciente da informação; é também armazenar informação e saber encontrá-la. É ser capaz de reconhecer e responder a mudança de padrões"(Johnson, 2001; 76).

Um exemplo desses reconhecidos padrões foi usado nos algoritmos do game SimCity (de Will Wright, 1989), um dos primeiros jogos a explorar os poderes da emergência: "cada célula está influenciando o comportamento das outras células, parecem surgir ondas de mudanças em todo o sistema, com uma fluidez e definição que só podem ser descritas como vivas" (Johnson, 2001; 65). São padrões de simulação de cidades baseados num truque de programação permitindo que a cidade do jogador evolua de uma forma parecida ao ser vivo. Assim, os usuários "amadurecem" suas cidades virtuais, "mas elas evoluem de modo imprevisível e o controle sobre a forma final da cidade é sempre indireto" (Johnson, 2001; 64). 


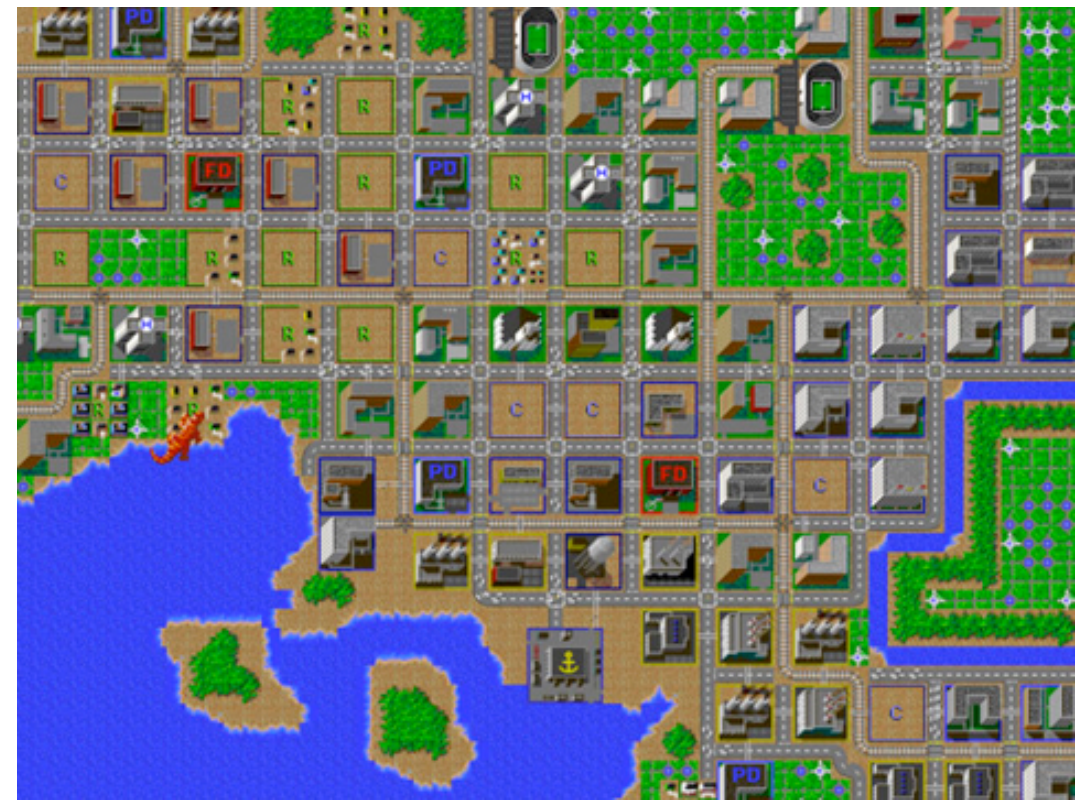

Fig $06-1^{\text {a }}$ geração do SimCity, 1989

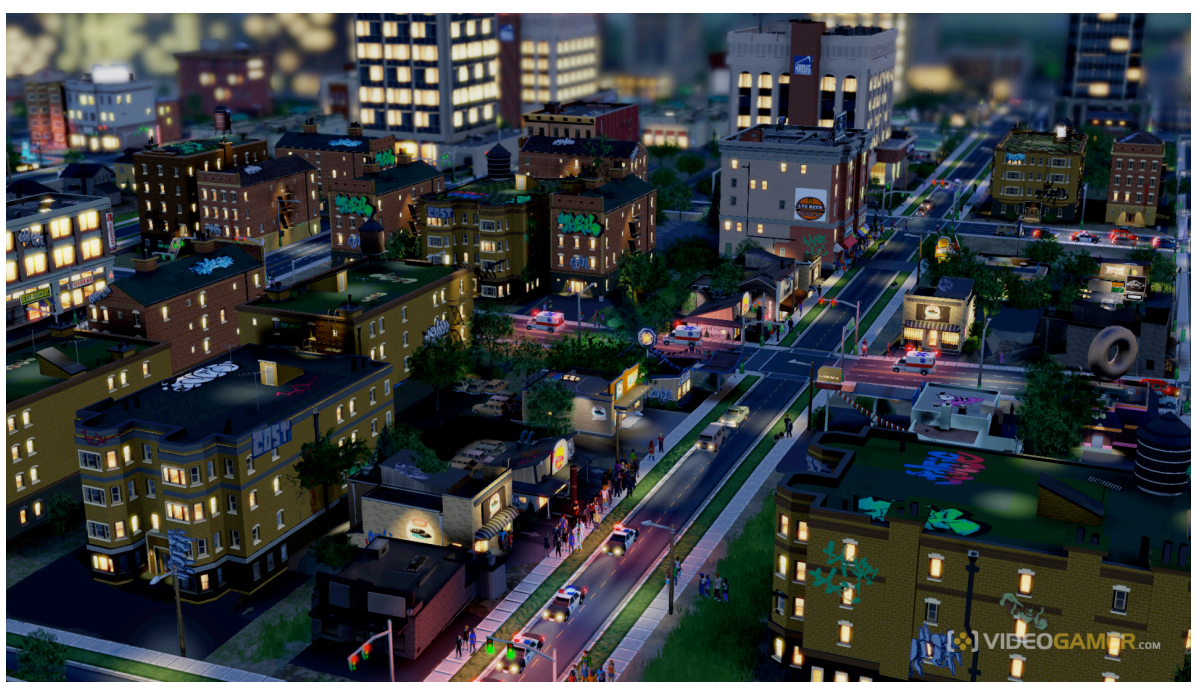

Fig 07 - Versão mais atual do SimCity, previsto para 2013

Simcity aborda a cidade como um sistema complexo de inter-relações a partir de algoritmos que possibilitam compreendê-la sob um ponto de vista amplo, aberto e quase divino. A chance de criar, organizar e gerenciar um espaço urbano permite adquirir uma outra relação, mesmo sendo ele virtual. Sendo ele um controle limitado, por mais que seja possível prever infra-estrutura adequada, projeções de crescimento, mas não há garantia de resposta do rumo de sua evolução. Se apresenta como tentativa de simular o cotidiano urbano contemporâneo, usando o sistema complexo como referente numa perspectiva de cidades atuais que possuem semelhanças e comportamentos sociais comuns, mas isso sob o ponto de vista da 
auto-organização, sem relação alguma com comportamento cultural, mas sim de seres vivos que convivem em comunidade. São algoritmos também usados para simular comportamento de outros seres e por isso Johnson os relaciona também às sociedades organizadas das formigas.

Sabe-se que a referência de cidade em SimCity foi inspirada na descoberta dos códigos DNA e toda lógica do sistema celular advinda com ela. Porém, podemos também identificar uma possível inspiração na concepção das chamadas cidades globais partindo do conceito de globalização, quando se especulava uma possível massificação cultural dos territórios urbanos. SimCity poderia ser a representação de qualquer cidade pois ali se encontravam ou encontram elementos comuns a muitas delas, tanto em relação à infra-estrutura quanto à paisagem.

O processo de globalização não ocorreu no momento em que ao qual o termo foi popularmente espalhado, pois desde a era moderna foi sendo traçado o caminho para que ela fosse concebida. A Revolução Industrial, as padronizações de produção e as medidas políticas, principalmente européias e americanas, facilitaram as relações entre os países com maior apelo econômico, um cenário construído em prol de benefícios territorialmente demarcados. A globalização como processo está em atividade desde 1945 (centrada mais nos Estados Unidos) e serviu como força motriz no processo como um todo, por meio da política externa, militar e comercial.

O termo "globalização", segundo Harvey (2000), parece ter adquirido proeminência quando a American Express fez uma propaganda difundida globalmente do seu cartão, na metade dos anos 1970. Ele acabou se espalhando e sendo muito bem aceito, encaixando-se perfeitamente às pretensões capitalistas da época. Representava um movimento que parecia inevitável, causando simpatia entre as massas. Tornou-se um conceito central associado ao admirável mundo novo, transformando-se em um poderoso instrumento político, dando a impressão de que estávamos entrando numa nova era.

Para Harvey, há outra questão que pode ter uma relevância profunda no processo globalizante: a imagem registrada por um satélite da NASA, mostrando a 
Terra como um símbolo em livre flutuação no espaço. "Essa imagem assumiu rapidamente o status de ícone de um novo tipo de consciência"(Harvey, 2000; 28).

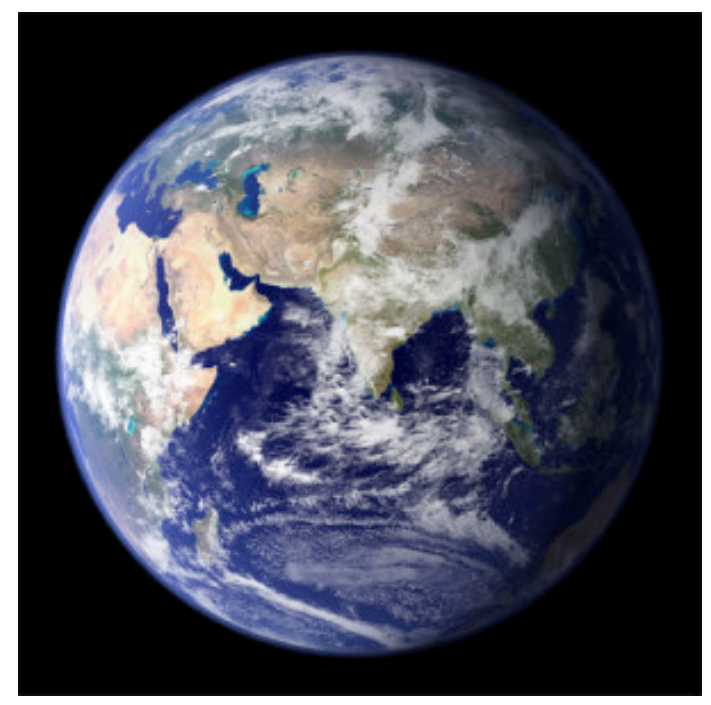

Fig 08 - Imagem da NASA publicada no final dos anos 60

A associação do conceito ao desenvolvimento tecnológico é freqüente, é muitas vezes associada à internet e todos os benefícios que proporcionam ao mundo, sendo quase o símbolo de um tempo, de uma nova era da informação e democratização, do "acesso a tudo", surgindo como um tipo de promessa de descentralização. Mas é importante lembrar que os aparatos tecnológicos foram sendo barateados e popularizados como uma estratégia comercial e não de difusão de informação. Já o conteúdo transgressor e a subversão do consumo com o compartilhamento não fazia parte do planejamento inicial.

McLuhan anunciou que os instrumentos eletrônicos teriam fins específicos no uso do poder:

No próximo século a terra terá a sua consciência coletiva elevada a superfície da Terra para uma densa sintonia eletrônica, em todas as nações - se continuarem a existir como entidades separadas - viverão feixe de sinestesia espontânea (...) O conceito de nacionalismo declinará e também os governos regionais cairão, como conseqüência política da criação de um governo mundial por satélite artificial. O satélite será usado como o mais importante instrumento mundial de propaganda de guerra pelos corações e mentes dos seres humanos (MCLUHAN and BRUCE, 1989; 95 e 118). 
Com a globalização surge o termo cidades globais. Elas possuem em comum: pontos de comando na organização da economia mundial; lugares e mercados fundamentais para indústrias de destaque; e, lugares de produção fundamentais para essas indústrias, incluindo a produção de inovações (Sassen, 1998; 16-17).

Canclini pontua como requisitos às cidades globais forte presença de empresas transnacionais, especialmente de organismos de gestão, pesquisa e consultoria; mistura multicultural de habitantes nacionais e estrangeiros; prestígio decorrente da concentração de elites artísticas, e cientificas; alta porcentagem de turismo internacional (Canclini, 2003; 155).O autor pontua a diferença entre as cidades globais e as emergentes, estas vivem na tensão entre expressões extremas da tradição e da modernização global. Elas continuam a abrigar populações que preservam hábitos residenciais e festas de origem rural. Para ele, o que faz, por exemplo, a Cidade do México e São Paulo. Estas cidades pertencerem a esse grupo não por suas condições de capitais regionais, ou suas conexões com um pais metropolitano, e sim pelo fato de terem se tornado focos decisivos de redes econômicas e comunicacionais de escala mundial.

\begin{abstract}
Nas cidades latino-americanas a segregação se organizou, durante o desenvolvimento modernizador, separando os grupos sociais em diferentes bairros. Depois, para ordenar a expansão urbana provocada pelas migrações e a industrialização desde meados do século, a população foi dividida sob a oposição centro-periferia: as classes médias e altas nas zonas centrais mais bem equipadas, enquanto os pobres se aglomeram em subúrbios desfavorecidos (...) Embora esse modelo continue a funcionar, diz Teresa P.R. Caldeira em seu estudo sobre São Paulo, dada a proximidade de diferentes grupos em muitas áreas da cidade, erguem-se muros, portões e guaritas, fecham-se bairros residenciais restringindo o acesso a suas ruas, constroem-se grandes edifícios com entradas controladas eletronicamente (CANCLINI, 2003; 163).
\end{abstract}

Sendo assim, a globalização como promessa de inclusão entre países, de trocas e desenvolvimento coletivo amplificado "entre povos", não ocorre nem mesmo dentro das cidades constituídas como globais. As grandes cidades ainda estão em constante inchaço populacional, na busca imaginada de civilização. 
Fica claro que a concepção de globalização e de cidades globais não se refere à questão da integração, unidade, espaço comum, mas sim aos impactos econômicos e trocas permanentes de informações via sistemas integrados. O território da cidade continua sendo referente à sua origem, história, memória e andamento.

Cada lugar nasce diferente do outro, dando ao todo da globalização um cunho nitidamente fragmentário, já que 'o lugar são todos os lugares'. Condição que leva Milton Santos (1996) a dizer que é o lugar que existe, e não o mundo, de vez que as coisas e as relações do mundo se organizam no lugar, mundializando o lugar e não o mundo (MOREIRA, 2007; 60-61).

Quando o termo "cidades globalizadas" foi instituído, falava-se sobre a perda de identidade e da semelhança entre as paisagens das cidades que faziam parte desse grupo. Muitos trabalhos artísticos apontaram esse dilema e talvez essa retomada de abordar as cidades nas obras, tenha sido influenciada pela necessidade de abordar o "global" num contraponto com o local, que também seria o que Milton Santos chama de "lugares".

No livro Local/Global: arte em trânsito (2005) de Moacir dos Anjos, o autor nos coloca a importância do tema nos últimos 20 anos na arte contemporânea. Sinaliza os eventos pioneiros evidenciando a discussão entre os pólos: "global e local são termos relacionais, assim como são centro e periferia" (2005; 15). Alguns trabalhos evidenciaram esse contraponto cultural, onde a força se reconhecia nos símbolos culturais e estéticos dos territórios, nas características únicas de cada lugar, contemplados nessas mostras citadas pelo autor.

Partindo dos conceitos de globalização, cidades globais e locais, Castells nos sugere que por mais que as cidades ao longo dos anos sejam cada vez mais caracterizadas como globais, continuamos habitando em lugares, agora conectados entre si. No obra A Sociedade em Rede (1999) o autor aponta as transformações políticas, sociais e econômicas da sociedade com o uso e troca constante de informações permitidos pelos interesses e avanços tecnológicos. O fato de estarem todos conectados pela rede não define que o território perca suas características essenciais.

A sociedade em rede difunde seletivamente em todo o planeta, trabalhando nos locais pré-existentes, organizações e instituições que 
ainda fazem a maior parte do ambiente material da vida das pessoas. A estrutura social é global, mas a maior parte da experiência humana é local, tanto em termos territoriais e culturais (CASTELLS, 1999; 471).

Para o autor (1999; 501), a nossa sociedade atual está construída em torno de fluxos, sendo eles fluxos de capital, informação, tecnologia, imagens, sons e símbolos, entre outros. Assim, há uma nova forma espacial que caracteriza as práticas sociais que moldam a sociedade em rede: o espaço de fluxos. Esse espaço é definido por camadas sendo a primeira constituída por um circuito de impulsos eletrônicos (telecomunicações, processamento computacional, sistemas de transmissão, etc.).

Sendo assim, a cidade atual pode ser reconhecida como um espaço de fluxos em camadas, o primeiro de circuitos eletrônicos, outro de infra-estrutura urbana (transporte público, encanamento, ruas, etc.) e dos grupos de pessoas. Moreira aponta à sociedade em rede essas camadas:

Com o desenvolvimento dos meios de transferência (transporte, comunicações e transmissão de energia), característica essencial da organização espacial da sociedade moderna - uma sociedade umbilicalmente ligada à evolução da técnica, à aceleração das interligações e movimentação das pessoas, objetos e capitais sobre os territórios -, tem lugar a mudança, associada à rapidez do aumento da densidade e da escala da circulação. Esta é a origem da sociedade em rede (...) a rede não é, portanto, um fenômeno novo. Recente é o status teórico que adquire (MOREIRA, 2007; 57).

No contexto do espaço de fluxos apontado por Castells, surge o conceito de cidade informacional, advindo da interação entre tecnologia, sociedade e espaço. Para Castells, podemos evoluir para cidades não mais globais, pois o conceito pressupõe os impactos agregadores da globalização, mas para cidades informacionais onde está implícita a ideia de espaço potencializado pelos dispositivos tecnológicos conectados e os dados trocados através dos mesmos.

Semelhante às cidades informacionais está o termo cibercidade, desenvolvido por Pierre Lévy no livro "Cibercultura" (1999), seria o ciberespaço permitindo relações com questões urbanas elaboradas através da comunicação interativa e coletiva, onde o cidadão passa a ter um status de atuação em ambos espaços: do 
território e do ciberespaço. Nos coloca que as ações sobre o território precisam enfrentar uma série de hierarquias e burocracias devido aos limites físicoestruturais, ao passo que no ciberespaço o funcionamento é mais transversal e fluído, criando uma nova potência que permite "compensar, no que for possível, a lentidão, a inércia a rigidez indelével do território por sua exposição em tempo real no ciberespaço" (Lévy, 1999; 195).

Para Lemos (2004), participar e ser cidadão hoje é estar conectado e atuar nas redes sociais do ciberespaço. A cibercidade é a cidade contemporânea onde a infraestrutura de telecomunicações e tecnologias digitais já é uma realidade, onde há relação entre cidade, urbano e as tecnologias sem fio.

Todas gerações de cidade estiveram ligadas por estruturas em rede, mas na cibercidade a conexão também é feita por redes telemáticas, inclusive nos serviços básicos oferecidos à população instaurando uma dinâmica distinta dos outros modelos de cidade. "As cibercidades passam a ser pensadas como formas de reestabelecer o espaço público, colocar em sinergia diversas inteligências coletivas, ou mesmo reforçar laços comunitários" (Lemos, 2004; 02). O maior interesse defendido pelos autores está em integrar os espaços e as maneiras de atuação em ambos, não há prevalência no ciberespaço sobre o território, mas sim um campo de força único, resultado da soma das camadas de inteligência e participação coletiva. É "aproveitar o potencial agregador da rede para o exercício da cidadania (...) o espaço de fluxo complexifica o espaço de lugar" (Lemos, 2004; 02-03).

Já Mitchell (2003) nos aponta que a evolução das cidades vai das necrópolis antigas, às cidades medievais muradas, passando às cidades industriais do século XX, chegando agora à cidade de bits.

No interesse de reunir estudo do cruzamento hibrido entre arte, urbanismo e tecnologia, os autores Valente e Germano buscam superar a dicotomia do que chamam de cidade real e cidade digital, pois há uma relação intrínseca entre elas que: "demanda uma reflexão sobre o conceito de cidade hibrida que se configura nos seus trâmites, partindo do conceito geopolítico ao tecnopolítico e vice-versa" (Valente e Germano, 2012; 11). Para isso adotam o termo cidade expandida, 
advindo do urbanismo mas que permite, segundo os autores, associações mais produtivas para a expansão conceitual.

Porém, atém ao possível equívoco de cair na tendência à crença ingênua somente ao associar arte, espaço urbano e tecnologia, não há relação direta com uma utilização crítica e alternativa. É importante destacar a grande diferença entre uso potencial e uso real e qual a intensidade exercida entre essas forças.

Se, de um lado, a cidade digital e seu potencial utópico podem exercer influencias e mudanças que renovem a cidade real, tanto em sua estrutura quanto em sua ordem econômica e ideológica, a exemplo de ações artísticas na internet e movimentos de contestação política organizados em redes sociais; de outro lado, essa expansão também representa reinauguração e/ou reforço de instâncias de poder, controle e opressão da cidade real sobre a cidade digital, numa mera reprodução do status quo e dos meios de produção já existentes (VALENTE e GERMANO, 2012; 20).

Vimos um breve percurso de alguns conceitos criados para pensarmos as cidades contemporâneas, principalmente a partir da popularização das redes de comunicação em tempo real e os conseqüentes impactos gerados na sociedade e nos espaços de convívio. Finalizamos com os termos mais associados a ações artísticas, o que nos traz ao nosso principal foco de interesse. Para compreendermos as manifestações atuais, é importante revelar os caminhos anteriormente percorridos quando as cidades passavam por uma grande transformação a partir do começo do século XIX. As produções realizadas naquele período afetaram as demais seguidas e ainda vemos atualmente a grande influencia que deixaram, tanto para os pensadores urbanos-sociais, quanto aos artistas.

\section{2 - a cidade na arte: movimentos e manifestos}

Faremos um percurso sobre os principais movimentos artísticos da história que continham a cidade como interesse temático e exploratório, do flâneur aos situacionistas; passando brevemente por alguns manifestos criados mais na atualidade.

O processo de urbanização surge a partir da Revolução Industrial, com a automatização dos meios de produção em grande escala trazendo às cidades infra- 
estruturas. A partir daí, foram surgindo na Europa as primeiras metrópoles, cidades centrais rodeadas por cidades de menor porte. Em grego, metropolis significa mãe + cidade, sendo assim as cidades são os nós centrais, comerciais, econômicos, políticos e artísticos da região a qual se instalava.

A transformação de cidade para metrópole foi ocorrendo rapidamente, na velocidade que somente a tecnologia mecânica desenvolvida na época poderia proporcionar. Com isso, houve uma grande mudança nas funções de trabalho, estilo de vida e no sistema urbano em si, a população inteira passou a se adaptar a uma nova configuração. O forte êxodo rural, a automatização da mão de obra, a grande concentração e circulação de pessoas, as indústrias, a finalidade de lucro do capital, davam inicio a um novo período da história ocidental.

Com o surgimento das metrópoles começam a aparecer ideias, produções literárias, artísticas, movimentos e manifestos que propunham um estar e atuar no espaço urbano de modo mais consciente, poético e subversivo; sugestionando um freio no comportamento social massificado que se instaurava.

Nesta lógica, pode-se considerar o flâneur como movimento pioneiro, associado ao século XIX, nasceu em Paris, e depois se espalhou pelo território europeu. O flâneur é a ação de estar no espaço público de modo descompromissado, encarando-o não somente como um ambiente de passagem entre um ponto e outro. O meio urbano e seus símbolos eram os elementos de observação e reflexão de um flâneur, atento aos fenômenos que cercavam as ruas, as casas, os comércios e o fluxo dos passantes.

Walter Benjamin foi um dos principais "leitores" do movimento, pois analisou e escreveu sobre a obra literária de Charles Boudelaire, considerado o grande representante do flâneur. Como comportamento comum, apontou:

A rua se torna moradia para o flâneur que, entre as fachadas dos prédios, sente-se em casa tanto quanto o burguês entre suas quatro paredes. Para ele, os letreiros esmaltados e brilhantes das firmas são um adorno de parede tão bom ou melhor que a pintura a óleo no salão do burguês; muros são a escrivaninha onde apóia o bloco de apontamentos; bancas de jornais são suas bibliotecas, e os terraços dos cafés as sacadas de onde, após o trabalho, observa o ambiente (BENJAMIN, 1994; 51). 
Enquanto a cidade crescia, enquanto eram construídas largas avenidas para a circulação de carros substituindo as ruelas, enquanto se aumentava a velocidade de tudo, o flâneur caminhava como tartaruga, simbolizando a resistência ao progresso acelerado. O objeto de interrogação do movimento foi a própria modernidade (BuckMors apud Bueno, 2009; 18).

Em suas produções, Boudelaire enfatizou a necessidade da experiência social para a prática artística, contrapondo a ação acadêmica de se fechar no estúdio para pensar no externo. Nos poemas, escrevia sobre o que lhe encantava: especialmente os tipos urbanos mais excluídos considerando-os como heróis modernos, era a existência de errantes, que circulavam nos subterrâneos da cidade, eram criminosos e mulheres de reputação equivocada.

No enrugado perfil das velhas capitais,

Onde até mesmo o horror se enfeita de esplendores,

Eu espreito, obediente os meus fluídos fatais,

Seres decrépitos, sutis e encantadores.

"As Velhinhas", As flores do mal. (Boudelaire, 1857 apud Benjamin, 1994)

Nas artes pictóricas do período, pode-se destacar duas obras inspiradas nos textos de Boudelaire e do flâneur: Dans La rue de Constantin Guys (1860) e La musique aux Tuileries de Édouard Manet (1862). Ambos retratam as multidões da época na rua e a beira do rio. A estética dos artistas não se aproximava daquelas que dominavam os salões de arte. Para Baudelaire, a multidão é para o flâneur como o ar aos pássaros, como a água o dos peixes. "Estar fora de casa, e contudo sentir-se em casa onde quer que se encontre; ver o mundo, estar no centro do mundo $e$ permanecer oculto ao mundo, eis alguns dos pequenos prazeres desses espírito independentes, apaixonados, imparciais, que a linguagem não pode definir senão toscamente"(Baudelaire apud Bueno, 2009; 33). 


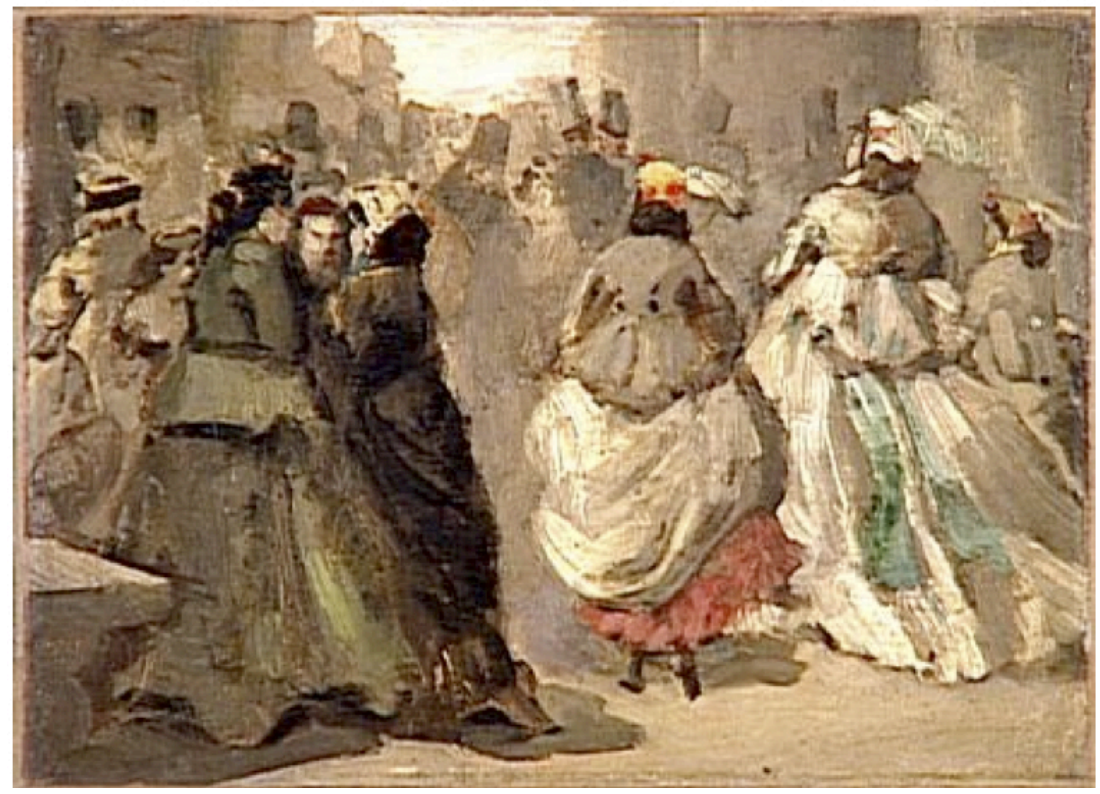

Fig 09 - Dans La rue (1860), de Constantin Guys

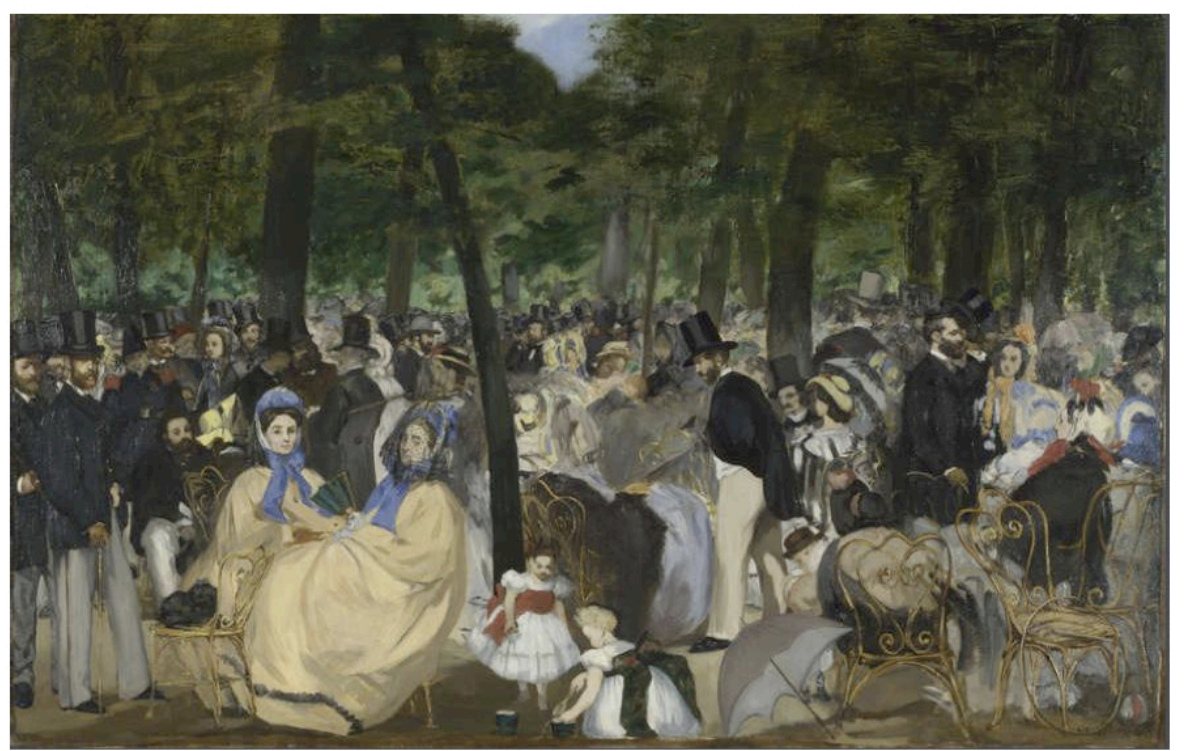

Fig 10 - La musique aux Tuileries (1862), de Édouard Manet

O flâneur se instaurou como um movimento a partir das obras literárias e pictóricas e não através de um manifesto coletivo contendo seus preceitos primordiais. Mas acreditamos ter sido o primeiro a incorporar a cidade como objeto de observação, reflexão e criação poética. A partir dele seguiram-se outros, cada um em seu tempo, referenciando as cidades de cada período. Seguiremos cronologicamente em alguns deles. 
O Futurismo foi fundado com a publicação de seu manifesto em fevereiro de 1909 no jornal Frances "Le Fígaro", escrito pelo poeta italiano Filippo Tommaso Marinetti. Proclamava, basicamente, a ruptura com o passado, instaurando a identificação do homem com a máquina, o dinamismo, a velocidade e o movimento do novo século. No manifesto, estava inserido o modo de vida ao qual o movimento defendia: uma atitude rebelde e radical, a arte como experiência, a frenesi urbana como estética sensorial. Através do manifesto, o movimento, iniciado na Itália, se espalhou pelos grandes centros europeus e marcou uma época tanto nas artes, quanto na produção industrial, pois muitos dos futuristas criaram campanhas publicitárias, logomarcas e embalagens de produtos. Separamos alguns trechos do Manifesto Futurista relacionados mais especificamente ao interesse dessa pesquisa ${ }^{1}$.

- Nós queremos cantar o amor ao perigo, o hábito da energia e da temeridade.

- A coragem, a audácia, a rebelião serão elementos essenciais de nossa poesia.

- Nós queremos exaltar o movimento agressivo, a insônia febril, o passo de corrida, o salto mortal, o bofetão e o soco.

- Nós afirmamos que a magnificência do mundo enriqueceu-se de uma beleza nova: a beleza da velocidade.

- Não há mais beleza, a não ser na luta. Nenhuma obra que não tenha um caráter agressivo pode ser uma obra-prima. A poesia deve ser concebida como um violento assalto contra as forças desconhecidas, para obrigá-las a prostar-se diante do homem.

- Nós estamos no promontório extremo dos séculos!... Por que haveríamos de olhar para trás, se queremos arrombar as misteriosas portas do Impossível? 9. Nós queremos glorificar a guerra - única higiene do mundo - o militarismo, o patriotismo, o gesto destruidor dos libertários, as belas idéias pelas quais se morre e o desprezo pela mulher.

- Nós queremos destruir os museus, as bibliotecas, as academias de toda natureza, $e$ combater o moralismo, o feminismo e toda vileza oportunista e utilitária.

\footnotetext{
${ }^{1}$ O Manifesto Futurista pode ser consultado na íntegra pelo link: http://entrelinhas.livejournal.com/53219.html (último acesso jan. 2013)
} 
- Vocês querem, pois, desperdiçar todas as suas melhores forças nesta eterna e inútil admiração do passado, da qual vocês só podem sair fatalmente exaustos, diminuídos e pisados?

- E venham, pois, os alegres incendiários de dedos carbonizados! Ei-los! Ei-los!... Vamos! Ateiem fogo às estantes das bibliotecas!... Desviem o curso dos canais, para inundar os museus!... Oh! a alegria de ver boiar à deriva, laceradas e desbotadas sobre aquelas águas, as velhas telas gloriosas!... Empunhem as picaretas, os machados, os martelos e destruam sem piedade as cidades veneradas! (TOMMASO, 1909) - (Grifos nossos).

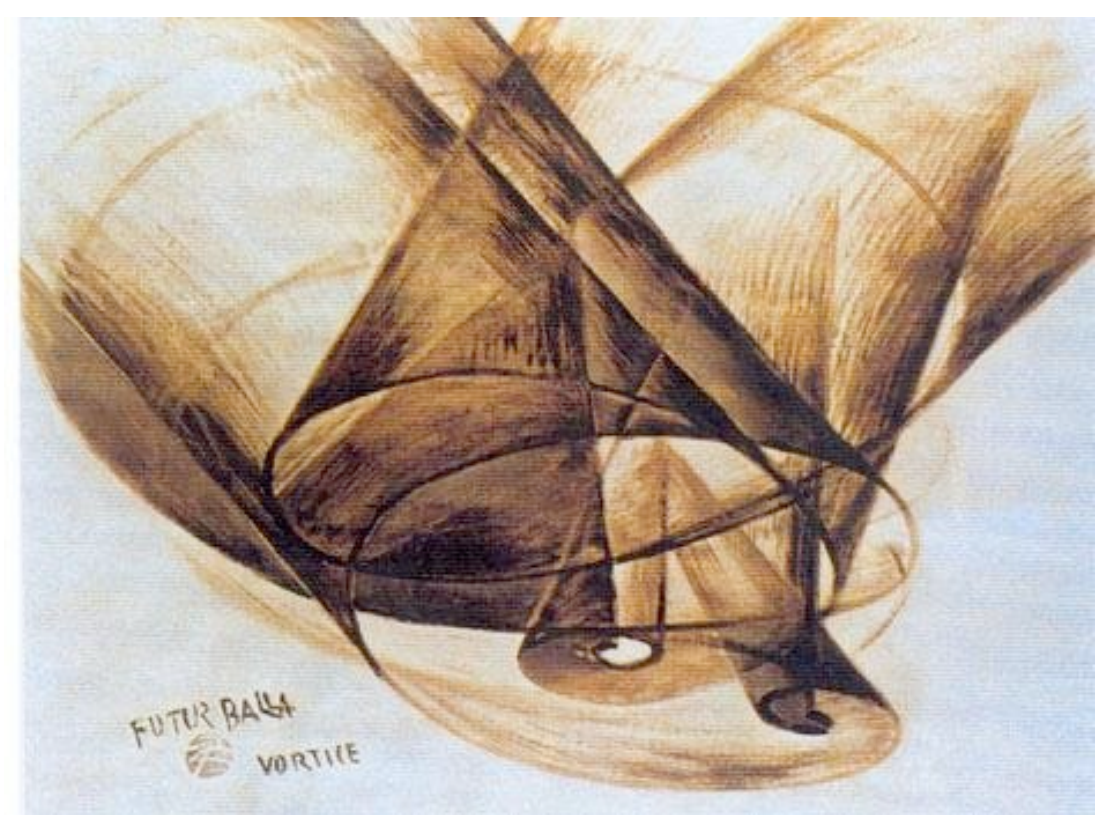

Fig 11 - Vortice (1914), do artista futurista Giacomo Balla

O manifesto estimulava a apreciação do "agora", indo contra qualquer atitude nostálgica e até mesmo crítica em relação as mudanças da época. Inclusive está nele a defesa da guerra e a condenação da participação feminina na sociedade. Atemos ao fato que o flâneur também era uma prática exclusivamente masculina. 0 futurismo parece ter sido um movimento anti-flâneur, só mesmo essa característica de exclusão da mulher os aproximam.

Durante a primeira guerra mundial, no ano de 1916, o Francês Tristan Tzara se refugiou na cidade de Zurique e começou a participar das célebres veladas do 
Cabaret Voltaire. Nesses encontros passa a liderar a fundação do grupo Dada que deu origem ao movimento dadaísta. O grupo era formado por escritores, poetas e artistas, alguns deles ex-combatentes. Criaram o Manifesto do senhor Antipirina, onde diziam estar decididamente contra o futuro, pois todos os universos possíveis eram vistos no presente. Destacamos alguns trechos:

DADA é a vida sem pantufas; que está contra e a favor da unidade $e$ decididamente contra o futuro.

Declaramos que o carro é um sentimento que nos mimou mais que o suficiente nas lentidões de suas abstrações, como os transatlânticos, os ruídos e as idéias. Por outro lado, exteriorizamos a facilidade, buscamos a essência central e nos sentimos felizes em poder ocultá-las.

DADA não é loucura, nem sabedoria, nem ironia, veja, gentil burguês.

Não somos naif

Somos sucessivos

Somos exclusivos

Não somos simples

E sabemos bem discutir com inteligência. Mas nós, DADA, não compartimos sua opinião, pois a arte não é coisa séria, os asseguro. (TZARA, 1963; 8-9. Tradução nossa).

Enquanto a cidade futurista era atravessada por fluxos de energia, por massas humanas em movimento, por automóveis, velocidade, luzes, ruídos e com metamorfose constante no espaço, a cidade Dada era a da banalidade que abandonava todas as utopias hipertecnológicas do futurismo (Careri, 2002).

Em 1918 lançaram o segundo manifesto intitulado Manifesto Dada, nele apontam as intenções mais claras do movimento, seguem alguns trechos:

DADA; abolição da memória: DADA; abolição da arqueologia: DADA; abolição dos profetas: DADA; abolição do futuro: DADA; crença absoluta indiscutível em cada deus produto imediato da espontaneidade; DADA; salto elegante e sem perda de uma harmonia à outra esfera; trajetória de uma palavra lançada como um disco 
sonoro; respeitar todas as individualidades em suas loucuras do momento: séria, medrosa, tímida, ardente, vigorosa, decidida, entusiasta; depenar sua igreja de todo acessório inútil do passado.

Liberdade: DADA DADA DADA, uivo das dores arranhadas, entrelaçamento dos contrários e de todas as contradições, do grotesco, das inconseqüências: A VIDA. (TZARA, 1960; 25-26) - (Tradução nossa).

Os Manifestos Dadas apesar de serem manifestos, pareciam ser contra qualquer tipo de dogma e a favor da expressão singela do cotidiano. Em 1921, após algumas tentativas, conseguiram realizar a primeira (e única) excursão dadaísta que consistia numa visita ao pátio da igreja de Saint-Julien-le-Pauvre, no centro de Paris. Um lugar aparentemente banal, que possuía um pequeno jardim na frente e poderia ser encontrado em qualquer outro lugar da cidade e o objetivo era esse mesmo, demonstrar que a arte poderia ser encontrar nos elementos mais banais (Costa, 2007).

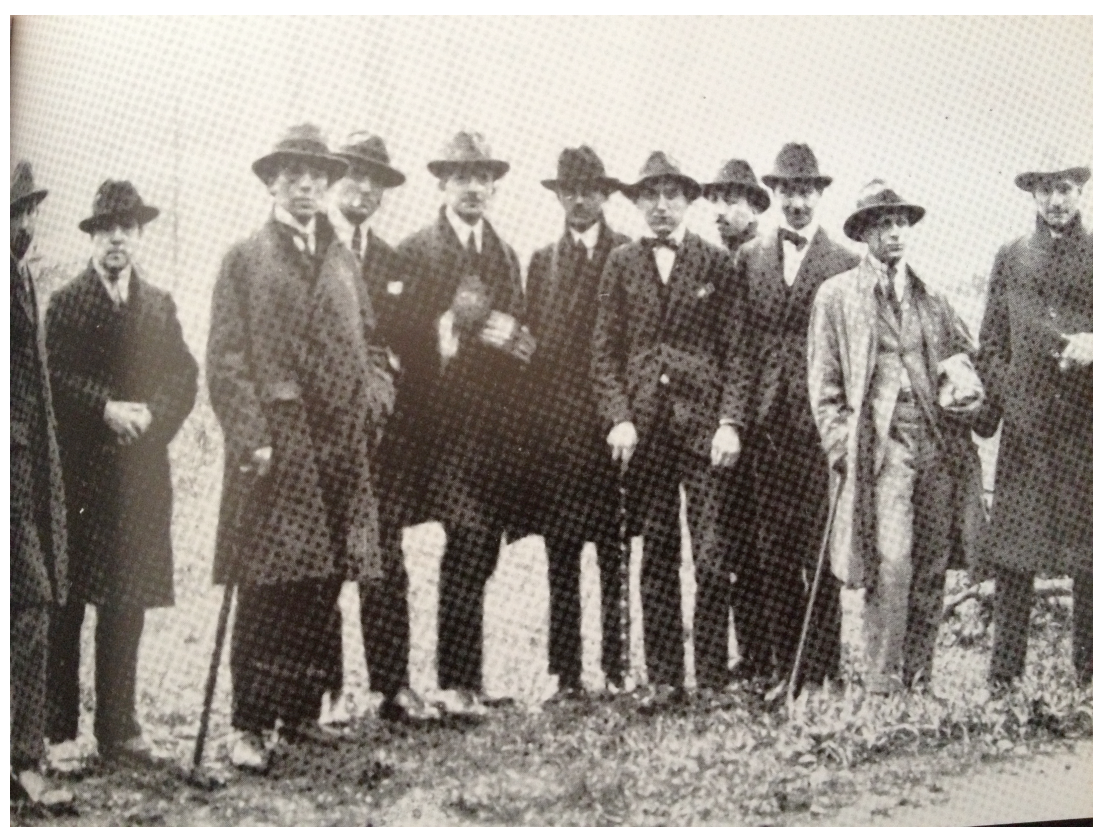

Fig 12 - Grupo dadaísta à saída da expedição (1921)

Careri nos aponta a fixação pela questão do movimento aos futuristas era representada de maneira tradicional: na pintura, esculturas, gravuras, ilustrações. $A$ partir da experiência da excursão dadaísta, a representação do movimento passa a 
ser a prática no espaço real. $\mathrm{O}$ ato de percorrer o espaço veio a ser utilizado como forma estética (Careri, 2002; 70).

As excursões dadaístas não deram procedência, mas marcaram os movimentos artísticos posteriores. Três anos após, em 1924, André Breton e mais outros integrantes dadaístas, herdeiros das veladas e do caminho à igreja Saint-Julien-lePavre, promoveram um novo percurso no espaço público. Essa viagem constituiu a materialização do lachez tout e simboliza o passo definitivo do Dada ao Surrealismo. Nessa caminhada não foi definido um roteiro até um ponto específico, a ideia era realizar um percurso errático por um vasto território natural. Considerada viagem pois não foi realizada na cidade de Paris, o grupo escolheu ao azar no mapa a pequena cidade Blois e seguiram de trem até ela. Durante dias caminhando e conversando, Breton a chamou de "deambulação a quatro bandas", sendo a "exploração até os limites da vida consciente e a vida sonhada". Na volta começa a esboçar o Manifesto do Surrealismo, onde define a palavra surrealismo como: "um automatismo psíquico puro mediante o qual se propõe expressar verbalmente, por escrito ou de qualquer outro modo, o funcionamento real do pensamento" (Breton, 1924).

A diferença entre excursão dadaísta e a surrealista está no fato da dadaísta ter sido focada nos elementos urbanos da cidade partindo de um ponto ao outro, enquanto que a surrealista se interessou num percurso errático e em territórios vazios em meio a natureza, no universo primitivo. No caminhar surrealista, Blois inaugurou o termo deambulação, que carrega o significado de alcançar, mediante o andar, um estado de hipnose, uma desorientação com perda de controle, onde se entra em contato com a parte inconsciente do território. A deambulação foi influenciada pelas pesquisas de Freud, pois era a busca por uma espécie de investigação psicológica do espaço e da paisagem. Alguns trechos do manifesto:

Ora, cheguei à psicologia, e com este assunto nem penso em brincar.

Ainda vivemos sob o império da lógica, eis aí, bem entendido, onde eu queria chegar. Mas os procedimentos lógicos, em nossos dias, só se aplicam à resolução de problemas secundários. O racionalismo absoluto que continua em moda não permite considerar senão fatos dependendo estreitamente de nossa experiência. Os fins 
lógicos, ao contrário, nos escapam. Inútil acrescentar que à própria experiência foram impostos limites.

A pretexto de civilização e de progresso conseguiu-se banir do espírito tudo que se pode tachar, com ou sem razão, de superstição, de quimera; a proscrever todo modo de busca da verdade, não conforme ao uso comum. Ao que parece, foi um puro acaso que recentemente trouxe à luz uma parte do mundo intelectual, a meu ver, a mais importante, e da qual se afetava não querer saber. Agradeça-se a isso às descobertas de Freud. Com a fé nestas descobertas desenha-se afinal uma corrente de opinião, graças à qual o explorador humano poderá levar mais longe suas investigações, pois que autorizado a não ter só em conta as realidades sumárias.

Swift é surrealista na maldade.

Sade é surrealista no sadismo.

Chateubriand é surrealista no exotismo.

Constant é surrealista na política.

Hugo é surrealista quando não é tolo.

Desbordes-Valmore é surrealista no amor.

Bertrand é surrealista no passado.

Rabbe é surrealista na morte.

Poe é surrealista na aventura.

Baudelaire é surrealista na moral.

Rimbaud é surrealista na prática da vida alhures.

Mallarmé é surrealista na confidência.

Jarry é surrealista no absinto.

Nouveau é surrealista no beijo.

Sanit-Pol-Roux é surrealista no símbolo.

Fargue é surrealista na atmosfera.

Vaché é surrealista em mim. 
Reverdy é surrealista em casa.

Saint-John Perse é surrealista a distância.

Roussel é surrealista na anedota.

Etc.

(BRETON, 1924)

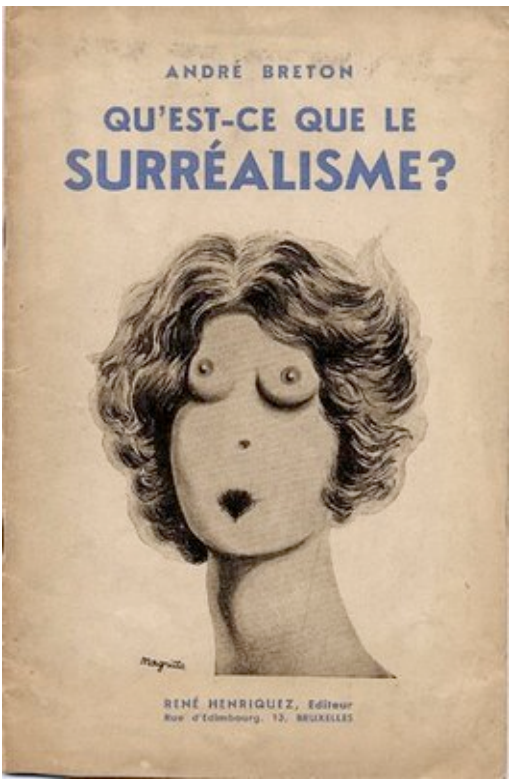

Fig. 13 - Capa do manifesto Surrealista de André Breton (1924)

Apesar de não ter sido expressado no manifesto, os surrealistas realizaram algumas deambulações durante o movimento, não somente em terrenos vazios, como ao redor do centro de Paris. Enquanto caminhavam, eram feitos mapas desses espaços e cidades a partir das percepções adquiridas nos locais percorridos. " $A$ investigação surrealista é uma espécie de investigação psicológica de nossa relação com a realidade urbana, uma operação já praticada com êxito, mediante a escritura automática e os sonhos hipnóticos, e que pode ser novamente proposta, inclusive atravessando a cidade" (Careri, 2002; 88).

O desenvolvimento maior do Surrealismo foi interrompido pela segunda guerra mundial. Em 1952, liderado pelo jovem Guy-Ernest Debord, é formado o grupo intelectual Internacional Letrista (IL). Até 1957 publicavam em dois periódicos 
franceses e com isso criaram e encabeçaram posturas políticas, comportamentais e artísticas que marcaram os anos 50 e 60.

Em seus artigos, a Internacional Letrista defendia o dadaísmo colocando que os surrealistas não souberam dar continuidade ao movimento, já que criticavam e negavam alguns dos preceitos Dadas. Para o grupo, as excursões não haviam sido bem desbravadas e por isso propunham um novo método de exploração do espaço. No texto Lé jeu psychogéographique de la semaine aparece pela primeira vez o termo psicogeografia, que acabou sendo a base desse novo movimento. Foi a união das referências, a excursão dadaísta e arte na banalidade, e a deambulação surrealista partindo do aleatório e da percepção psicológica do território.

Em 1957 o grupo passa a se chamar Situacionistas, ainda com Guy Debord como líder. Era período de pós-guerra e os situacionistas lançavam um movimento antiarte com finalidade de subverter o sistema capitalista vigente, assumindo o espaço como meio estético-político. O comportamento nesse momento foi construído a partir da deriva, uma atividade lúdica coletiva, com intuito de materializar um modo alternativo de habitar à cidade e um estilo de vida contra as regras da sociedade burguesa. Para os situacionistas, a deambulação surrealista fracassou por terem dado demasiada importância ao inconsciente e ao azar, a deriva previa o encontro da realidade objetiva com a percepção afetiva. Para eles, não havia separação entre a vida real e a vida imaginária maravilhosa. Jacques sintetiza o significado de psicogeografia e deriva:

A psicogeografia foi definida como um 'estudo dos efeitos exatos do meio geográfico, conscientemente planejado ou não, que agem diretamente sobre o comportamento afetivo dos indivíduos'. E a deriva era vista como um 'modo de comportamento experimental ligado às condições da sociedade urbana: técnica da passagem rápida por ambiências variadas. Diz-se também, mais particularmente, para designar a duração de um exercício contínuo dessa experiência.'(...) A deriva seria uma apropriação do espaço urbano pelo pedestre através do andar sem rumo". (JACQUES, 2003; 22).

O espaço para os situacionistas deveria ser experimentado e descoberto como um jogo. Fazer parte, assumindo-o como seu, subvertendo as normas préestabelecidas, questionando seu uso, sua forma e criando formas estéticas 
revolucionárias anti-controle. Opunham-se à cultura do espetáculo, à alienação, à passividade, à não participação e ao não questionamento. "Assim, o espaço urbano se configurava como terreno ideal para a ação, a produção de novas formas de luta, de intervenção, de reação contra a monotonia da vida moderna"(Costa, 2009; 32).

O Manifesto Internacional Situacionista foi publicado em 1960, após algumas intervenções no espaço público, quando o movimento já estava bem estruturado. Destacamos as partes que mais nos interessam:

Uma nova força humana, que o status existente não poderá reprimir, cresce a cada dia com o irresistível desenvolvimento técnico e com a insatisfação de sua utilização possível em nossa vida social privada de sentido.

A alienação e a opressão na sociedade não podem ser mantidas em nenhuma de suas variantes, mas sim, apenas rejeitadas em bloco com essa mesma sociedade. Todo progresso verdadeiro fica evidentemente suspenso até que a multiforme crise atual encontre uma solução revolucionária.

Quais seriam as perspectivas de organização da vida numa sociedade que, de maneira autêntica, "reorganizasse" a produção sobre a base de uma associação livre e igualitária de produtores? A automatização da produção e a socialização dos bens vitais reduzirão cada vez mais o trabalho como necessidade exterior $e$ proporcionarão, finalmente, plena liberdade ao indivíduo. Desse modo, liberto de toda responsabilidade econômica, de todas as suas dívidas e culpas com relação ao passado e ao seu próximo, o homem terá à sua disposição uma nova mais-valia incalculável em dinheiro, pois essa mais-valia não pode ser reduzida à medida do trabalho assalariado: o valor do jogo, da vida livremente construída. O exercício dessa criação lúdica é a garantia da liberdade de cada um e de todos no âmbito da única igualdade garantida com a não-exploração do homem pelo homem. $\underline{A}$ libertação do jogo é a sua autonomia criativa, que supera a velha divisão entre o trabalho imposto e o ócio passivo.

A Igreja queimou, em outras épocas, supostos bruxos para reprimir as tendências lúdicas primitivas conservadas nas festas populares. $\mathrm{Na}$ sociedade dominante de hoje, que produz em massa desconsolados pseudo-jogos de não- 
participação, uma atividade artística verdadeira é forçosamente classificada no campo da criminalidade. É semiclandestina. Aparece sob a forma de escândalo.

O que é isso, na verdade, a não ser a situação? Trata-se da realização de um jogo superior, mais exatamente, da provocação para jogar esse jogo que constitui a presença humana. Os jogadores revolucionários de todos os países podem unir-se à 1.S. a fim de começar a sair da pré-história da vida cotidiana.

A partir de agora, propomos uma organização autônoma dos produtores da nova cultura, independente das organizações políticas e sindicais existentes no presente momento, pois nós negamos a capacidade de se organizar outra coisa a $\underline{\text { não ser o acondicionamento do existente. }}$

O objetivo mais urgente que estabelecemos para uma primeira campanha pública dessa organização quando ela sair de sua fase experimental inicial é a tomada da U.N.E.S.C.O. A burocratização unificada, em escala mundial, da arte e de toda a cultura é um fenômeno novo, que expressa o profundo parentesco entre os sistemas sociais coexistentes no mundo, que se baseiam na conservação eclética e na reprodução do passado. A resposta dos artistas revolucionários a essas novas condições deve ser um novo tipo de ação. Como a existência mesma dessa concentração direcionada da cultura, localizada num único edifício, favorece a sua confiscação por meio de um putsch; e como a instituição carece completamente de possibilidades de um uso que tenha sentido fora de nossa perspectiva subversiva, sentimo-nos justificados, diante dos nossos contemporâneos, para nos apoderarmos de um tal aparato. E o faremos. Estamos decididos a nos apoderar da U.N.E.S.C.O., ainda que seja por pouco tempo, já que estamos seguros de nela realizar, rapidamente, uma obra que permanecerá como a mais significativa, pelo fato de esclarecer um longo período de reivindicações.

Quais deverão ser principais características da nova cultura, principalmente em comparação com a arte antiga?

Contra o espetáculo, a cultura situacionista realizada introduz a participação total.

Contra a arte conservada, é uma organização do momento vivido diretamente. 
Contra a arte unilateral, a cultura situacionista será uma arte do diálogo, da interação. Os artistas - como toda a cultura visível - chegaram a estar completamente separados da sociedade, assim como estão separados entre si pela concorrência. Porém, inclusive antes que o capitalismo ingressasse nesse pântano, a arte era essencialmente unilateral, sem resposta. Essa era encerrada em seu primitivismo será superada graças a uma comunicação completa.

Até que todo o mundo chegue a ser artista num plano superior, isto é, inseparavelmente produtor-consumidor de uma criação cultural total, assistiremos à dissolução rápida do critério linear de novidade. Quando todo o mundo for situacionista, por assim dizer, assistiremos a uma inflação multidimensional de tendências, de experiências, de "escolas" radicalmente diferentes, e isso não mais sucessivamente, mas sim, simultaneamente.

Inauguramos agora o que será, historicamente, o último dos ofícios. O papel de situacionista, de leigo-profissional, de anti-especialista, é, no entanto, uma especialização até o momento de abundância econômica e mental em que todo o mundo chegará a ser "artista", num sentido que os artistas não alcançaram: a construção de sua própria vida.

Aos que não nos compreenderam bem... dizemos-lhes com um irredutível desprezo: os situacionistas, de quem vocês acreditam ser juízes, os julgarão mais cedo ou mais tarde. Nós os esperamos na mudança de sentido que é a inevitável liquidação do mundo da escassez em todas as suas formas. São esses os nossos objetivos, e serão os futuros objetivos da humanidade. (SITUATIONNISTE, 1960) (Grifos nossos).

No manifesto fica clara a intenção político-artística do movimento, um convite para um novo comportamento civil no espaço urbano, para uma compreensão mais profunda e intensa do mesmo. Se coloca, entre todos os demais, naquele que simboliza de maneira enfática a integração entre o homem, a cidade e a arte, possivelmente por ter incorporado pontos fortes de cada um deles.

As derivas situacionistas resultaram em muitas obras de pintura, fotografia, cinema e também de mapas da cidade de Paris que incluíam mais elementos além 
do espaço geográfico. Eram informações, referências, conexões afetivas e sociais que relacionavam bairros e regiões não pela proximidade física, mas por esses outros tipos de questões. Era o próprio principio da psicogeografia expresso em planos feitos com colagens.

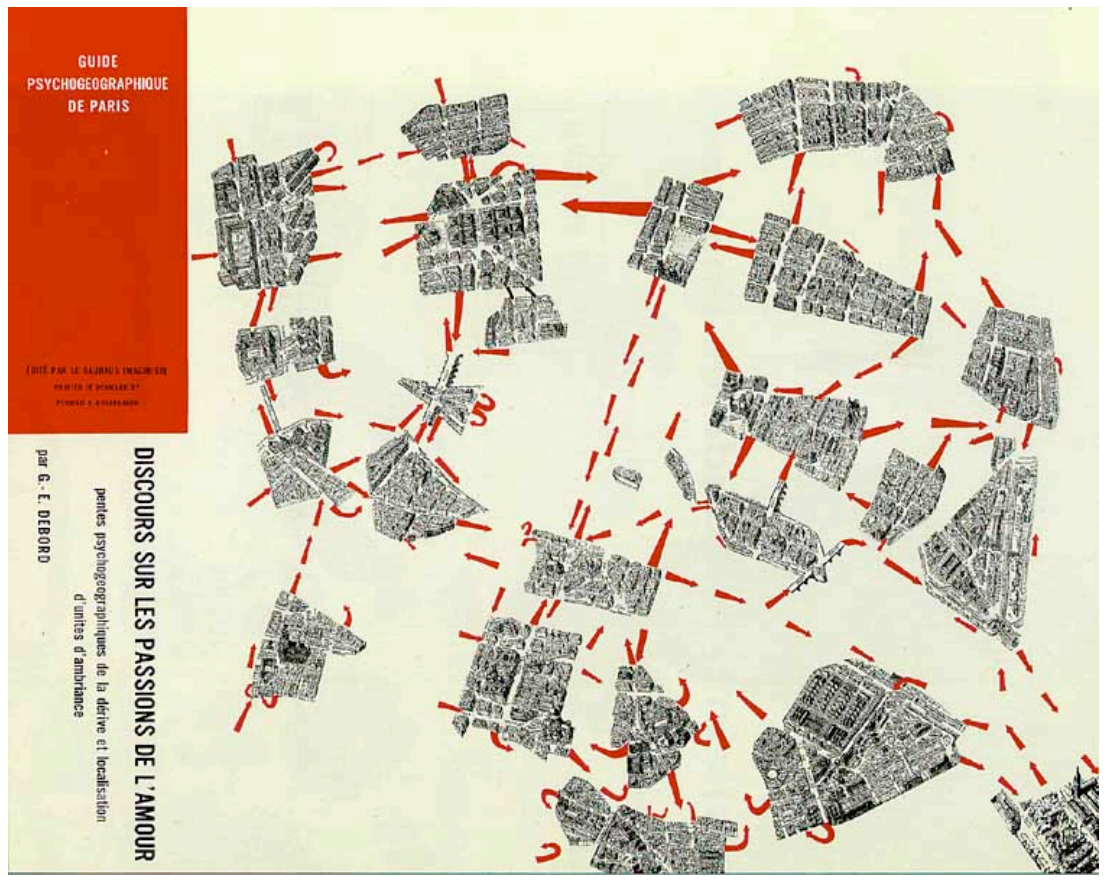

Fig. 14 - Guia psicogeográfico de Paris (1957), Guy Debord

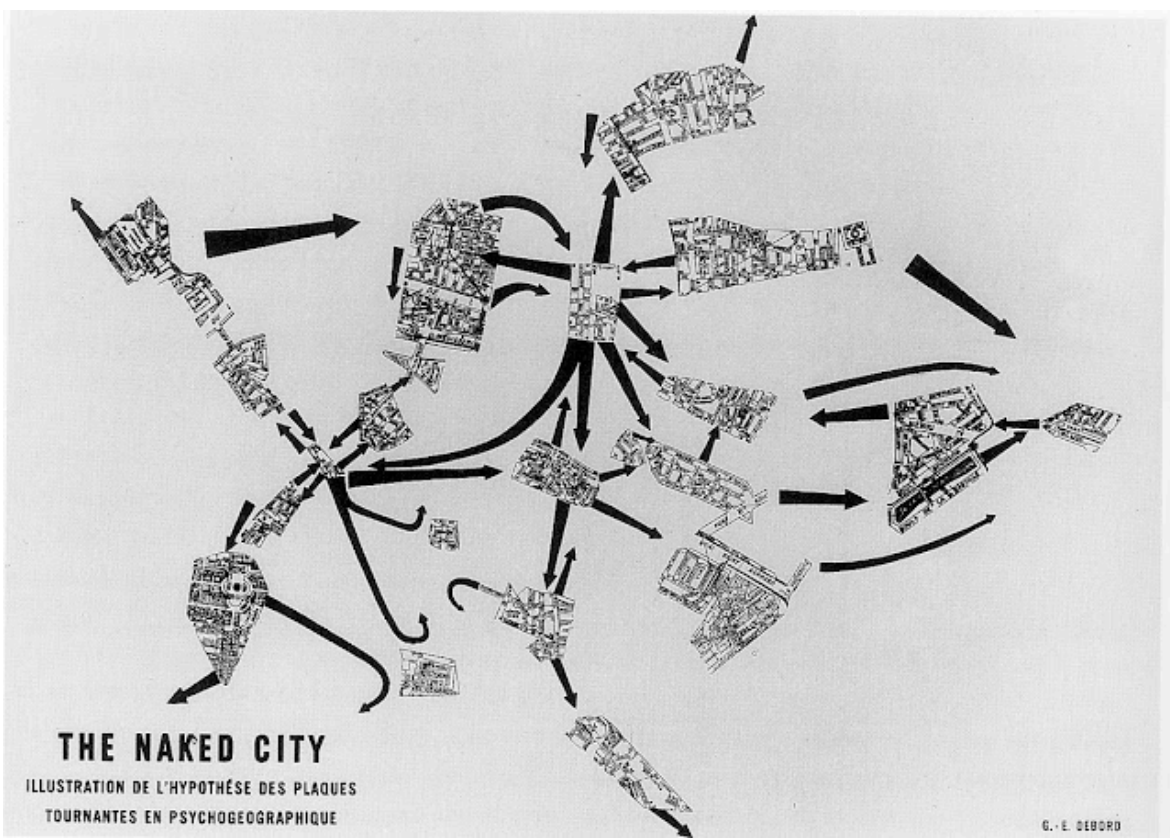

Fig 15 - The naked city (1957), mapa-obra criado por Guy Debord 
Fizemos um percurso histórico dos movimentos artísticos que estimularam e propuseram novas práticas de perceber e vivenciar a cidade, de modo a intensificar a experiência no espaço. Sabemos da influência ainda presente atingidas em muitas áreas de conhecimento como o urbanismo, as artes, antropologia, geografia e filosofia. Os manifestos marcavam a clareza e a intenção dessas propostas, sempre focados no tempo ao qual estavam inseridos.

No Brasil, podemos identificar como importante manifesto o Antropofágico, escrito por Oswald de Andrade em 1928, mas não continha relação com a cidade mas sim com o nacionalismo do artista brasileiro.

Outro manifesto bastante relevante foi o Caranguejos com Cérebro, dando início ao movimento de contracultura Mangue Beat, da década de 90. Refere-se à cidade de Recife e à necessidade de falar com o mundo:

A planície costeira onde a cidade do Recife foi fundada, é cortada por seis rios. Após a expulsão dos holandeses, no século XVII, a (ex) cidade "maurícia" passou a crescer desordenadamente às custas do aterramento indiscriminado e da destruição dos seus manguezais. Em contrapartida, o desvairio irresistível de uma cínica noção de "progresso", que elevou a cidade ao posto de "metrópole" do Nordeste, não tardou a revelar sua fragilidade. Bastaram pequenas mudanças nos "ventos" da história para que os primeiros sinais de esclerose econômica se manifestassem no início dos anos 60. Nos últimos trinta anos a síndrome da estagnação, aliada à permanência do mito da "metrópole", só tem levado ao agravamento acelerado do quadro de miséria e caos urbano. O Recife detém hoje o maior índice de desemprego do país. Mais da metade dos seus habitantes moram em favelas e alagados. Segundo um instituto de estudos populacionais de Washington, é hoje a quarta pior cidade do mundo para se viver.

O que fazer para não afundar na depressão crônica que paralisa os cidadãos? Como devolver o ânimo deslobotomizar e recarregar as baterias da cidade? Simples! Basta injetar um pouco da energia na lama e estimular o que ainda resta de fertilidade nas veias do Recife. Em meados de 91 começou a ser gerado e articulado em vários pontos da cidade um núcleo de pesquisa e produção de idéias pop. $O$ objetivo é engendrar um "circuito energético", capaz de conectar as boas vibrações 
dos mangues com a rede mundial de circulação de conceitos pop. Imagem símbolo, uma antena parabólica enfiada na lama. Os mangueboys e manguegirls são indivíduos interessados em: quadrinhos, tv interativa, anti-psiquiatra, Bezerra da Silva, Hip Hop, midiotia, artismo, música de rua, John Coltrane, acaso, sexo nãovirtual, conflitos étnicos e todos os avanços da química aplicada no terreno da alteração e expansão da consciência.

(ZERO QUATRO, 1992) - (Grifos nossos).

O Mangue Beat também consistia numa atitude participativa no espaço da cidade, a música foi a principal bandeira a partir de onde o movimento passou a ser reconhecido com as bandas Chico Sciense e Nação Zumbi, Mundo Livre S.A., Mestre Ambrósio, Eddie, entre outras. Mas também estava inserido nas artes plásticas, fotografia, cinema e até na moda.

Importante destacar a referência da geração Beat ao Movimento Mangue, inclusive no nome. Foi a geração que marcou o fim dos anos 50 e início dos 60 , formado por poetas norte-americanos que escreviam sobre um estilo de vida boêmio, nômade, de busca espiritual, e acabaram sendo chamados de delinqüentes pela sociedade. Foram o embrião do movimento hippie, com obras como One the Road (Jack Kerouac), Howl (Allen Ginsberg) e Naked Lunch (Willian Burroughts). Nelas estavam inseridas uma nova postura social: espontânea e livre.

Mais atualmente, inspirados no uso generalizado das novas tecnologias móveis e das redes sociais, podemos citar dois manifestos: o Manifesto Nômade escrito por Tom-B em 2001 e o Mobile and Open: Manifesto, de Howard Rheingold, 2005.

Podemos citar alguns trechos para referência, tratando das posturas sóciopolíticas que os usuários podem adquirir com o uso tecnológico. No Nômade:

Liberte-se do tempo e do espaço. Pra que acordar de manhã e bocejar em uníssono com o resto da cidade? Pra que enfrentar congestionamentos só para se deslocar até um cubículo odioso cuja única função é te colocar sob a vigilância de bedéis e babás? Faça o seu trabalho fluir através dos fios.

Trabalhe nu. 
Por enquanto você ainda vai estar preso: a fios de telefone e ethernet; à área de cobertura do seu celular. Mas fique esperto: daqui a vinte minutos o céu vai se coalhar de satélites e você vai poder sair correndo pra praia.

Arme-se! Os monolitos do poder não verão com bons olhos esses bandos de freaks correndo por aí, vivendo de produção intelectual pura, cagando pras regras do passado industrial. Fique ligado em criptografia, em redes de contatos e nos caminhos da economia.

(TOM - B, 2001) - (Grifos Nossos).

O Manifesto Mobile atém-se ao uso consciente e que poderia ser útil a uma sociedade mais restrita ao território, ao bairro e também diz respeito a nossa atuação como indivíduos e cidadãos no espaço.

The techno-political battle is whether widely embraced open standards dominate, a proprietary monopoly emerges, or many competing proprietary standards contend.

Everybody should have the freedom to associate information with places and things, and to access the information others have associated with places and things.

Will the people at fifth and main have the right and power to read and write information about their neighborhood, or will the owner of a local franchise purchased from the city by a private interest (think about the way cable television operates) dominate?

(RHEINGOLD, 2005) - (Grifos Nossos).

Nesse caminho feito sobre os movimentos e manifestos, vemos que a cidade e o comportamento social nela formado, gerou interesse nos intelectuais e artistas desde a concepção urbana. Parece que vivemos mais uma dessas fases, agora mediada por aparelhos conectados em rede, GPS e as camadas de dados gerados por esse intenso fluxo: nas ruas e nos cabos. 


\section{3 _ cidade mediada}

Nos últimos anos vimos uma transformação bastante significativa no comportamento urbano. O caminhar apressado e o deslocamento no trânsito passaram a ter um novo elemento junto ao corpo: os aparelhos celulares. Com o tempo, esses aparelhos foram deixando de ser somente um meio móvel de conversa e incorporaram outras funções: envio de mensagens de texto, registro e edição de imagens, ,GPS, internet 3G, jogos e mais recentemente aplicativos de toda natureza.

Nunca foi tão evidente a colocação de McLuhan de que os meios de comunicação são extensões do homem. Esses pequenos aparelhos simbolizam a coexistência de espaços paralelos, mas que cada vez se cruzam mais: o espaço da cidade e o espaço da web. Não há peso ou níveis de importância, se é real ou virtual, espaço concreto ou espaço digital, há a sobreposição que criou uma nova potência, camadas de interação, fruição e participação. São realidades vividas simultaneamente, nas ruas e nos links. Inclusive os posicionamentos antagônicos, tais como local versus global, individual versus coletivo ou contemplativo versus interativo, já não fazem mais tanto sentido, sobretudo na arte mídia atual.

Também já não é mais relevante encarar esses aparelhos como simples aparatos. Segundo Lemos (2010), as mídias em rede atuais não podem ser pensadas como "tubos" por onde passam informações. Não como dispositivos por onde passam coisas, mas como aquilo que se faz da relação e do movimento entre as coisas/informações. Ou seja, daquilo que se cria a partir do fluxo entre as trocas e a colaboração mútua que ocorre nos espaços sociais da rede.

O termo mídias locativas surge para explicar o caráter referente ao lugar e ao que se constrói dele e sobre ele com as mídias móveis, oferecendo suporte para a compreensão da relação que foi adquirindo com o espaço:

Podemos definir mídias locativas como dispositivos, sensores e redes digitais sem fio e seus respectivos bancos de dados 'atentos' a lugares e contextos. Dizer que essas mídias são atentas a lugares e a contextos significa dizer que elas reagem informacionalmente aos mesmos, sendo eles compostos por pessoas, objetos e/ou informação, fixos ou em movimento. O que conta, a partir da mobilidade física e informacional (Keerman, 2006), é a relação dinâmica desses dispositivos com o lugar e as trocas informacionais daí advindas. Emergem aqui duas dimensões 
fundamentais da cibercultura: localização e mobilidade (LEMOS, 2009; 91).

Há também outros termos que definem ações remotas entre espaços online e físico, menos usadas, porém que reconhecem esse tipo de conduta:

\begin{abstract}
A experiência de movimentar-se ou atuar remotamente, por parte do usuário web, em um outro ambiente físico é reconhecida por alguns autores como teleoperation e implica na existência de um outro dispositivo nesta relação. Para Manovich (2001) o termo mais adequado seria teleactiion para esta atuação remota capaz de afetar outras localidades sem a necessidade da presença física do participante nestes mesmos ambientes (MACIEL \& CRUZ, 2004; 276).
\end{abstract}

Esses conceitos definem o que se opera nos lugares e no entre-lugares através dos dispositivos mediadores. São conseqüências já cotidianas de uma comunicação e atualização permanente dos sistemas integrados.

A cidade, o espaço onde as pessoas vivem, são afetados com a atuação das mídias locativas em vários níveis. Desde o comportamento do corpo-usuário já citado, à percepção do espaço mediado por esses dispositivos e num nível mais intenso, à reação coletiva de encontro organizados nas redes sociais. Desse último exemplo podemos citar os flash mobs ${ }^{2}$ como fenômeno (mesmo que publicitário), as manifestações populares como do $15 \mathrm{M}^{3}$ na Europa e os ativismos políticos articulados concomitantemente: na rede web e na cidade.

Nas cidades informatizadas, podemos reconhecer algumas transformações também nos serviços oferecidos à população: nos meios de transporte, comércio, pagamento de contas, nos dados cívicos, nas câmeras de vigilância pública, entre outros. Além de digitalizados são, muitas vezes, geolocalizados. Há uma camada invisível enquanto circulamos, que mapeia o fluxo de tudo que se está passando entre as ruas.

\footnotetext{
2 Flash mobs são aglomerações instantâneas de pessoas para realizar determinada ação, em geral inusitada, previamente combinada e organizada em reuniões via redes sociais online.

$315 \mathrm{M}$, também conhecido como "movimento de los indignados", foi um movimento civil formado em 15 de maio de 2011 para uma série de protestos políticos pacíficos realizados na Espanha, ao qual mobilizou milhões de pessoas em todo país com organização feita através das redes sociais.
} 
No texto Why do we need new intarfaces to understand cities better? (2008), Mahir Yavuz propõe a elaboração de novas interfaces que nos permitam não só compreender como visualizar melhor as cidades. Para ele os mapas ainda continuam sendo a melhor forma de representação do espaço, porém os geográficos já não suprem as informações necessárias da cidade atual. Com essas novas interfaces, poderíamos compreendê-las e transformá-las em ambientes melhores para se viver. O mapa de Yavuz seria dividido em quatro camadas: meio físico, dados de detalhes espaciais, conjunto de dados agrupados (sociais), valores locais/regionais e manipulação em tempo real. Para o autor, essas camadas organizadas ofereceriam suporte para um mapa complexo, completo e em constante atualização, como a própria cidade. São dados já encontrados, porém não agrupados numa interface única. Um projeto que explorou algumas das potencialidades citadas por Yavuz foi o Real Time Rome ${ }^{4}$ (2006), realizado pelo Senseable City Lab, do MIT. Consiste num mapa de Roma via aplicativo de celular, onde é possível ver o tráfico de ônibus e taxis das ruas em tempo real.

Weissberg nos aponta à inversão de valores ocorrida, quando essas informações deixam de ser apoio e passam a ser o interesse primordial:

O território foi colonizado pelo universo informacional, que ele manifestaria, então, como simples substrato, alimento de base nutrindo o espaço informacional que tenderia a obliterá-lo. Ao invés de seguir esta via - a do recobrimento do território pelo mapa - parece-me mais interessante destacar a reterritorialização das informações, interpretar o crescimentos dos S.I.G. como o indicio de uma força que compele para a espacialização da informação (WEISSBERG, 2004; 119).

E continua:

A afiliação à rede significa localização em um espaço ao mesmo tempo não geográfico e territorial. Bem o demonstram os sistemas de posicionamento por satélite (como G.P.S.), que se emancipam da geografia física, mas sempre garantindo a localização. Entretanto, com a exibição da localização, o mapa geográfico retoma seus direitos, combinando, assim, espaço físico e espaço informacional. Neste sentido, a rede vence o território sem o subjugar (WEISSBERG, 2004; 121).

\footnotetext{
${ }^{4}$ http://senseable.mit.edu/realtimerome/ (último acesso out. 2012)
} 
Há, desse modo, o revés dessa relação: as informações passam de um "extra", para fazerem parte integrada do que se reconhece como cidade e como território em geral.

Vemos projetos de realidade aumentada (Azuma, 1997) na cidade com a função de potencializá-la com novos dados, tendo o suporte da rede e das mídias locativas. Como colocou Weissberg, eles combinam o espaço físico ao informacional, abordam temas como os patrimônios históricos da cidade ${ }^{5}$, os graffitis dispostos nas ruas ${ }^{6}$, a arte urbana sem assinatura ${ }^{7}$, o patrimônio imateral já destruído ${ }^{8}$, os pontos turísticos e a memória da cidade ${ }^{9}$ e para facilitar a mobilidade urbana ${ }^{10}$.

O interesse está na visualização, integração, processamento e cruzamento entre esse dados, pois eles fazem parte da cidade como nós mesmos. Salingaros usa o termo fractal city e explica como é a vida na cidade atual:

The life of a city is directly dependent upon its matrix of connections and substructure, because the geometry either encourages or discourages people's movements and interactions. Such an understanding is crucial for superimposing the electronic city driven by Information and Communication Technologies. Contrary to what is widely assumed, the electronic city is not an automatic outgrowth of the "high-tech" modernist car city, but in fact connects much better to the more humanscaled 19th century city (SALINGAROS, 2005; 134).

Por mais que o fluxo de informação não pare de ser gerado e atualizado, que o sistema urbano esteja todo conectado e simbolize a cidade atual, no meio estão as pessoas e os lugares ainda centralizando as ações realizadas, impactando e decidindo esses caminhos.

Diz-se que a vida urbana conectada é uma rede de redes, isso porque a cidade em si já era ligada por infra-estruturas em rede como de saneamento, energia

\footnotetext{
${ }^{5}$ www.mubevirtual.com.br (último acesso out. 2012)

6 http://www.streetartview.com/ (último acesso out. 2012)

7 http://www.urbanartguide.com/ (último acesso out. 2012)

8 http://www.cabanyalarchivovivo.es/DERIVAS manu.html (último acesso out. 2012)

9 http://www.museumoflondon.org.uk/Resources/app/vou-are-here-app/home.html (último acesso out. 2012)

${ }^{10} \mathrm{http}: / /$ senseable.mit.edu/rio/ (último acesso out. 2012)
} 
elétrica, água, transporte, telefonia, entre outros. Isso simboliza uma lógica sobre a outra, hoje, integradas entre si.

Os lugares ainda não perderam seu caráter original como se previa no início do discurso da globalização. Ainda habitamos lugares como disse Milton Santos, mas esse já não pode ser definidos da mesma maneira. Parece-nos que chegamos no momento em que as heterotopias de Foucault são vividas absolutamente nas cidades: os espaços das alteridades, da simultaneidade físico, mentais e agora digitais se mostram presentes em todas instâncias.

\begin{abstract}
A hora actual pode ser um pouco espaço de tempo. Estamos na era do simultâneo, estamos na época da justaposição, a época do lado mais próximo e distante, ao lado, do disperso. Estamos em um momento em que o mundo está enfrentando, creio eu, pelo menos como uma grande vida que se desenvolverá ao longo do tempo como uma rede que conecta pontos e cruza-se com a sua meada (FOUCAULT, 1984; 01).
\end{abstract}

Essa justaposição de espaços, culturas, de conexão em rede, das atuações remotas e simultâneas, coloca as heterotopias como alternativa para a compreensão do agora, do estar entre e ao mesmo tempo.

Assim como a heterotopia, há ainda o conceito de heterocronias, a respeito de nossa relação com o tempo contemporâneo. No livro Heterocronías: tiempo, arte y arqueologias del presente (2008), de Miguel Navarro (Org) o autor aborda a sensação desse tempo corrido, frenético e desenfreado que sentimos e compartilhamos. Para ele, uma das primeiras conseqüências da globalização foi a imposição da "hora ocidental", da hora hegemônica do tempo global sugerindo a eliminação dos diversos tempos locais e individuais. Assim como o espaço, o tempo tende a ser homogeneizado. Por isso, é preciso integrar ambos "tempos" para a concepção de uma nova possibilidade:

Las teorias contemporâneas de la hibridación cultural abohan también por una hibridación temporal. Junto a una tercera via o un tercero espacio, también podría hablarse de un tercer tiempo (...) Una especie de in-between del tiempo en el que seria posible la hibridación de temporalidades, donde las especificidades temporales locales y globales coexistirian sin problemas (NAVARRO, 2008; 76). 
Com os dispositivos móveis o tempo e o espaço são modificados no decorrer do acontecimento, mesmo sendo no plano da percepção e sensação. Assim, as heterotopias e heterocronias seriam um apoio definidor nesse momento que sentimos a integração entre os sistemas sobrepostos, que seguirão convivendo e possivelmente reconhecidos como força única.

A postura mais ativa e participativa obtida com o uso das mídias em rede, pode contaminar a postura cotidiana da vivência no espaço público. Observamos, hoje, o encontro desses lugares heterotópicos nas cidades, quando se articulam reuniões públicas em praças para protestar, defender um ideal, ou mesmo realizar um pic-nic coletivo. Há um movimento em torno de um resgate dos espaços comuns, de assumir a cidade como sua, de um desligamento gradativo do privado em prol do público. Isso talvez seja uma conseqüência do uso das redes sociais que representam esse espaço comum a todos.

O ativismo político da atualidade está completamente inserido nesse contexto:

De gran importancia en la evolución del ativismo durante los últimos quince años ha sido la cada vez más eficaz sinergia entre la actividad política de disensión en las redes y la desarrollada en el espacio de las calles; una progresiva síntesis de los movimientos sociales con la tecnologia; un intenso compromiso de la acción creativa colectiva en el ámbito de la red con la crítica cultural y política (...) Esto es, dar lugar al desarrollo y configuración de lo que se ha venido a denominar una "globalización desde abajo" (PRADA, 2012; 71).

A atuação mútua acontece em alguns níveis além do político, aquilo que se evidencia como tendência na web é revertido nas cidades, tanto no que se refere aos atos cívicos como nos modismos efêmeros. Algo que transcende aos locais aos quais o fenômeno ocorre, seja em São Paulo ou Madri, a circulação imediata em rede dissemina e se manifesta ao mesmo tempo.

Isso não quer dizer que essas cidades percam suas identidades essenciais e passem a configurar paisagens homogêneas, globais. Há elementos comuns devido ao contágio recíproco, porém a paisagem dos locais permanece única assim como as experiências obtidas nos mesmos. Eles se comunicam, integram, trocam, mas não são um só. 
No domínio da interatividade oferecida pelas novas ferramentas digitais no ciberespaço, os territórios geográficos aparentemente desaparecem, substituídos pelos espaços virtuais. Ao contrario disso, entretanto, várias propostas reafirmam que o individuo se encontra em lugares que permanecem interferindo em seu olhar, em suas percepções e em suas relações afetivas (BULHÕES, 2011; 95).

No interesse de propor essa reflexão, artistas passaram a criar trabalhos em mídias locativas promovendo diferentes maneiras de percepção do espaço geográfico. Nesse contexto, é importante sinalizar o significado de Paisagem, pois não se refere somente ao espaço observado: "a paisagem, deve ser considerada como objeto de apropriação estética, sensorial. Consequentemente, não se pode negar que ela tenha uma natureza objetiva, que seja um objeto" (Menezes apud Sanderville; 2005, 03).

A paisagem da cidade conectada talvez ainda não seja representada ou até mesmo experimentada esteticamente, a não ser pelas obras de alguns artistas. Segundo Brissac (2003; 428), o modelo urbanístico e cartográfico da paisagem da cidade atual, não reflete as mudanças que vêem ocorrendo nos usos contemporâneos que se fazem da mesma, e menos ainda das relações criadas através dos novos meios tecnológicos. Para ele, os novos procedimentos deveriam levar em consideração a complexidade e indeterminação do espaço urbano, potencializando as conexões geradoras de novos acontecimentos e configurações.

Talvez algumas intervenções de arte urbana dêem conta de simbolizar essas participações de espaços concomitantes. Por serem efêmeras e pontuais, posicionadas em lugares específicos e fluidas, por representarem um pensamento coletivo e adequado ao espaço do acontecimento, por co-existirem na cidade e na web e fazerem sentido somente por essa possibilidade. Como nos coloca Silva:

Em vez de transferir a comunicação para os espaços digitais (que desprezam as distancias geográficas), as tecnologias nômades possibilitam a comunicação à distancia enquanto se move pelo espaço urbano. É provável que as tecnologias nômades não mudem o formato geográfico das cidades, como o fez a ferrovia no século XIX, mas possivelmente influenciarão o modo como compreendemos as cidades e as navegamos. Dentro deste contexto, as obras de arte hibridas reinterpretam os espaços públicos e/ou usam espaços virtuais para 
modificar os espaços físicos, transformando padrões de sociabilidade e de interação humana em áreas especificas (SILVA, 2004; 283).

Nesse contexto podemos dizer que a vida urbana é uma rede de redes, o interessante é descobrir e propor as potencialidades oferecidas através da arte. Vimos que a relação de arte e cidade esteve presente desde a modernidade e nesse momento não é diferente, a cidade contemporânea é desafiada a se revelar através das proposições oferecidas com as mídias locativas, muitas vezes realizadas com a participação coletiva. Afinal, rede de redes se alimenta de movimento e participação.

Algumas obras apontam essas questões, e poderemos refletir mais profundamente no assunto no capítulo a seguir. 
CAP.03-REDES E CIDADES 


\section{CAP 03 _ redes e cidades_análise de obras}

Neste capítulo, faremos análise de algumas obras artísticas com propostas de participação e que tenham as cidades como inspiração poética. O princípio comum entre elas é a utilização das redes em relação com os espaços urbanos. Iniciaremos com uma descrição dos trabalhos e seguiremos com as reflexões tendo por base os conceitos históricos e teóricos abordados nos capítulos anteriores, concentrando atenção no tema de interesse da presente pesquisa.

Os trabalhos analisados foram elaborados a partir de 2.000 , período relevante de exploração das mídias locativas nos espaços públicos urbanos. Buscou-se abordar exemplos não somente de autores e obras reconhecidos, como também de grupos mais emergentes e mesmo de ações coletivas na web que resultaram num movimento colaborativo espontâneo. Isso porque esses trabalhos foram relevantes para a produção artística autoral no escopo desta pesquisa. Refletir sobre elas foi a melhor maneira encontrada de compreender seus procedimentos criativos em relação às suas abordagens.

As obras foram dividas em tags temáticas relacionadas ao que consideramos como possibilidade de identificar e reconhecer a cidade contemporânea e as produções artísticas de âmbitos variados aplicadas a elas. Também podemos relacionar com maior facilidade os enfoques mais presente abordados, não que sejam únicos, mas com evidência os mais marcantes. As mesmas tags ajudaram nos experimentos artísticos realizados durante a pesquisa, iluminando os caminhos e definindo a força poética de cada uma delas.

Em memória foram incluídas obras que utilizassem o espaço da cidade e da web como possíveis meios de registro histórico e afetivo, onde os edifícios e as nuvens de dados serviram como suporte de criações e recriações de significado urbano. Remap foi uma expressão criada tendo como inspiração o remix. Remap é uma tag para abordar trabalhos que realizem remarcações no território, pontos que se relacionam não somente pelo espaço geográfico da cidade, mas por qualquer outro contexto criado pelos artistas. 
A tag fluxos refere-se às obras que explorem os fluxos urbanos como referência, tanto para uma possível visualização gráfica dos mesmos, como para captura dos dados e interferência no sistema criado. Em deslocamento nos acercamos de propostas que abordem o trânsito, os meios de transporte e o caminhar na essência criativa. Por fim, em paisagens reunimos trabalhos que sugerem a percepção de paisagens possíveis, além da nitidez trivial.

Muitas delas poderiam pertencer a mais de um grupo das tags, porém buscamos incorporá-las ao que se via pertencer de maneira mais intensa e a partir daí nos valemos de uma aproximação íntima junto ao tema. 


\section{1 _ memória}

O início da manifestação do graffiti foi marcado por mensagens de protesto e desabafo político nos muros de Paris e logo de outras cidades européias, a partir dos anos 50. Esses registros gráficos também podem ser refletidos como registro histórico de períodos específicos de cada cidade.

Com o passar dos anos, o graffiti foi virando símbolo de urbanidade, sendo parte integrante das paisagens de grandes cidades. Ao imaginarmos símbolos urbanos, já reconhecemos o graffiti como um dos grandes componentes, mesmo sendo uma atitude ilegal na maioria dos lugares. Com o tempo e principalmente em algumas grandes cidades passaram a ser símbolo estético, adquirindo reconhecimento artístico. Alguns desses artistas tornaram-se representações de períodos históricos na arte assim como criaram marcas próprias em suas cidades de atuação: a Nova York de Basquiat e Keith Haring, a São Paulo de Alex Vallauri e a Londres de Banksy. Como nos coloca Campos:

Actualmente o graffiti pode ser entendido como um sinal da urbanidade contemporânea, da globalização cultural e da intensificação dos circuitos de comunicação mas, igualmente, como o resultado local da inventividade das culturas juvenis e da capacidade dos diferentes actores para agirem na epiderme da sua cidade(...) graffiti é, pois, inseparável de uma ideia de cidade (CAMPOS, 2009; 05).

Com o advento da rede internet e das redes sociais, muitos dos trabalhos realizados nas ruas passaram a ser registrados e comentados entre os grupos interessados no tema, possivelmente causando influências entre grafiteiros de todo mundo, revertidas nos traços e linguagens expressadas.

O graffiti globalizou-se embora não se tenha uniformizado. Distintas realidades revelam as habilidades criativas dos agentes locais na reinvenção dos utensílios culturais. Todavia, algo em comum distingue estas expressões de tantas outras que podemos encontrar no habitat urbano. Os exercícios que dão origem ao graffiti revelam uma vontade de atribuição de um novo sentido à cidade (CAMPOS, 2009; 02).

Os encontros nas redes e a prática nas cidades acabam gerando um ciclo de ações interessante, onde não há início ou fim de uma história da prática artística, 
pois acaba tudo sendo retornado à rede e a partir daí aberta a novas resignificações. Através das redes sociais são criados ambientes próprios para a troca de informações e referências, inclusive nos grupos interessados por arte urbana. $\mathrm{Na}$ arte, esse fenômeno vem crescendo e transformando os processos de criação. Em bate-papo realizado na Livraria Cultura (em 27/11/2010, São Paulo), mediado por Fábio Cypriano e intitulado: "A inserção da street art no universo da arte contemporânea", estavam presentes alguns grafiteiros da cidade de São Paulo, e um dos pontos foi o reconhecimento da ferramenta das redes como elemento essencial na produção atual do graffiti.

O grupo apontou à prática cada vez mais comum de obras desenvolvidas coletivamente a partir do contato das redes sociais. Um dos exemplo são os artistas Mundano ${ }^{11}$ e Ozi $^{12}$, que realizaram trabalhos coletivos em muros da cidade. Duas das utilizações mais freqüentes para esse fim são as páginas do flickr.com ${ }^{13}$ e do facebook. $\operatorname{com}^{14}$.

Apesar do reconhecimento e consenso coletivo do graffiti ser uma prática que traz "vida" às cidades, é uma ação ilegal. Por isso, é comum se tomar conhecimento da autoria dos trabalhos somente através das redes. No mesmo bate-papo citado, os artistas comentaram da primeira aproximação entre eles que havia sido realizada via flickr e facebook. Esses encontros por vezes geram produções conjuntas e dessa forma, o encontro por meio da web acaba afetando diretamente a arquitetura da cidade.

As obras em graffiti não duram muito, são efêmeras e essa é uma das características desse tipo de produção. Sendo assim, as redes sociais online oferecem um espaço de armazenamento histórico daquilo que cedo ou tarde se perderá, são uma espécie de acervo com curadoria aberta e participativa da memória de muros e da própria configuração urbana de determinados períodos.

\footnotetext{
${ }^{11} \mathrm{http}: / /$ www.flickr.com/photos/artetude/ (último acesso em jan. 2012)

${ }^{12} \mathrm{http://www.flickr.com/photos/graffitivivo/} \mathrm{(último} \mathrm{acesso} \mathrm{em} \mathrm{jan.} \mathrm{2012)}$

${ }^{13}$ http://www.flickr.com/

${ }^{14}$ www.facebook.com
} 


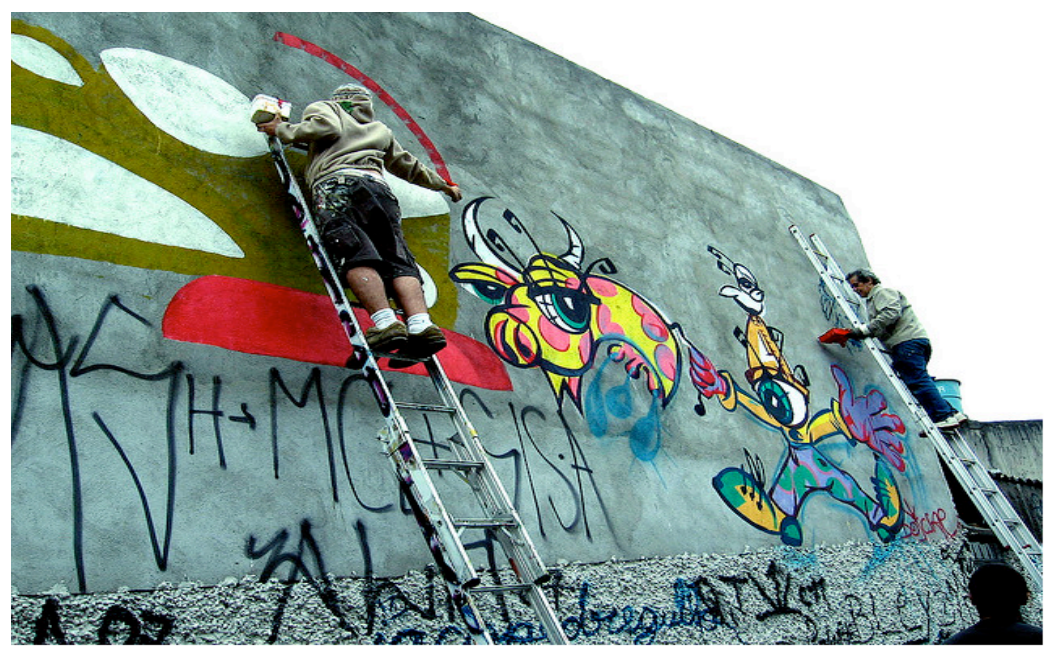

Fig. 16 - Muro sendo criado por Ozi e Mundano, imagem disponível no flickr de Ozi

Nesse sentido, o projeto colaborativo Olhe os $\operatorname{Muros}^{15}$, criado por Eduardo Perazza e Gabriela Serio, também pode ser citado como exemplo relativo ao mesmo fenômeno. Em entrevista ${ }^{16}$ concedida ao Caderno Link, do jornal O Estado de São Paulo, a dupla conta ter se conhecido na web, uniram interesses comuns às mensagens dispostas nos muros de São Paulo e criaram um twitter $^{17}$ para compartilhamento de imagens feitas de frases grafitadas nos muros. Nenhum dos dois é artista de rua, apenas se interessam pelo tema. Hoje o tumblr do projeto possui mais de 40 mil seguidores e imagens que chegam a ter mais de 25 mil compartilhamentos na web. Não há intuito de criação artística e sim de uma curadoria livre e coletiva dos trabalhos expostos nas paredes das ruas. Nesse caso, o foco aos muros partindo de uma proposta online, estimula a um comportamento cotidiano mais atento ao que se passa no espaço público. A intenção dos autores é de transformar o site num acervo eletrônico ou museu digital de arte urbana.

Os álbuns e pastas criados nesses espaços para armazenar seus conteúdo, guardam a imagem de uma cidade de seu tempo, são como os álbuns de nossas infâncias, álbuns de família abertos para relembrar um passado. Ali estão não somente os registros dos graffitis, como também de períodos específicos da cidade.

\footnotetext{
${ }^{15} \mathrm{http}: / /$ olheosmuros.tumblr.com/ (último acesso jan. 2013)

${ }^{16}$ entrevista: http://blogs.estadao.com.br/link/outro-olhar/ (último acesso jan. 2013)

${ }^{17}$ www.twitter.com (último acesso jan. 2013)
} 